\title{
COMPETÊNCIAS FUNDAMENTAIS PARA PROFESSORES DE UMA INSTITUIÇÃO DE ENSINO MÉDIO DO DISTRITO FEDERAL
}

\section{Clarissa Schmidt da Rocha}


Universidade de Brasília

Faculdade de Economia, Administração, Contabilidade e Ciências da Informação e Documentação

DEPARTAMENTO DE ADMINISTRAÇÃO

TRABALHO DE CONCLUSÃO DE CURSO

\section{COMPETÊNCIAS FUNDAMENTAIS PARA PROFESSORES DE UMA INSTITUIÇÃO DE ENSINO MÉDIO DO DISTRITO FEDERAL}

\section{Clarissa Schmidt da Rocha}

Professor Orientador:

Maria de Fátima Bruno de Faria, Doutora.

"Trabalho apresentado em cumprimento às exigências acadêmicas parciais da disciplina Estágio Supervisionado em administração para a obtenção do grau de Administradora"

Brasília - DF

Julho/2009 
Rocha, Clarissa Schmidt da.

Competências fundamentais para professores de uma Instituição de ensino médio do Distrito Federal / Clarissa Schmidt da Rocha. - Brasília, 2009.

57f. : il.

Monografia (graduação) - Universidade de Brasília, Departamento de Administração, 2009.

Orientadora: Prof. Dra. Maria de Fátima Bruno de Faria, Departamento de Administração

1. Competências profissionais. 2. Ensino Médio. 3. Desempenho Docente 
Universidade de Brasília

Faculdade de Economia, Administração, Contabilidade e Ciências da Informação e Documentação

DEPARTAMENTO DE ADMINISTRAÇÃO

\title{
COMPETÊNCIAS FUNDAMENTAIS PARA PROFESSORES DE UMA INSTITUIÇÃO DE ENSINO MÉDIO DO DISTRITO FEDERAL
}

\begin{abstract}
A Comissão Examinadora, abaixo identificada, aprova o Trabalho de Conclusão do Curso de Administração da Universidade de Brasília da aluna
\end{abstract}

\section{Clarissa Schmidt da Rocha}

Maria de Fátima Bruno de Faria, Dra.

Professora-Orientadora

Pedro Meneses

Professor-Examinador

Brasília, 7 de Julho de 2009. 
Ao meu tripé base de sustentação, que eu amo incondicionalmente e que sempre me apóia e me dá força: meu pai Ricardo, minha mãe Margarete e minha irmã Beatriz. 
AGRADECIMENTOS

Às pessoas do colégio Marista que foram essenciais para o desenvolvimento deste trabalho: Alessandra, Marcelo Coutinho e José Leão.

Aos alunos, professores e gestores que contribuíram para o sucesso da pesquisa com as participações nos grupos focais.

À AD\&M, que me permitiu ser uma profissional melhor e que foi determinante na opção pelo tema do meu trabalho.

À minha amiga Carol Kozlowski que, de forma inconsciente, sempre me inspirou a fazer um trabalho melhor.

Aos amigos que ouviram desabafos, e trocaram experiências e conhecimentos neste momento da monografia: Michel Lopes, Vitor Peixoto, Victor Machado e Carol Kozlowski (novamente).

Às minhas grandes amigas e amigos que compreenderam as minhas ausências momentâneas para "monografar" e sempre estavam disponíveis quando era preciso descontrair.

À professora Fátima que de forma tão brilhante e apaixonada me ensinou grande parte do que apresento aqui.

À minha mãe, meu pai e minha irmã pela paciência, compreensão, parceria e amor incondicional.

A todos os meus familiares, de sangue ou de coração, que são fundamentais na minha vida e me dão força.

A Deus, pela vida maravilhosa que eu tenho e pela oportunidade de realizar o sonho de ser uma Administradora formada pela Universidade de Brasília. 


\section{RESUMO}

Este trabalho tem por principal objetivo identificar e descrever as competências fundamentais para que um professor de ensino médio apresente um desempenho de qualidade. Com base na literatura pesquisada relacionada a competências, ao ensino no Brasil e seus docentes, buscou-se fundamentar o estudo, bem como optar pelo modelo de descrição de competências sob referenciais de desempenho, que define a competência como comportamentos passíveis de observação no ambiente de trabalho. Para tanto, foi escolhida uma escola do Distrito Federal como organização a ser estudada: o Colégio Marista. A pesquisa consistiu em análise documental e principalmente realização de grupos focais com alunos, professores e gestores, de forma a coletar as diferentes percepções sobre competências docentes. Foram realizados dois grupos focais com alunos, um com professores e um com diretores, totalizando 26 participantes. Foram identificadas 29 competências no total. Destas competências, oito foram extraídas das falas de todos os grupos, assim como dos documentos. Outras 15 competências foram identificadas por apenas uma destas fontes. Estas competências são igualmente importantes uma vez que expressam características essenciais ao desempenho docente, de acordo com a literatura e a política institucional. No caso dos alunos, predominaram competências desejáveis para a aprendizagem efetiva. Já os gestores contribuíram com competências relacionadas a atividades externas à sala de aula, e que são importantes para o aperfeiçoamento da prática docente. A pesquisa documental, por sua vez, contribuiu com aspectos de responsabilidades do professor como profissional do colégio Marista. Observou-se que as competências identificadas neste estudo se assemelham a algumas outras identificadas em estudos de outros autores. Os resultados encontrados permitirão à Organização utilizá-los de forma a avaliar o desempenho de seus docentes e estabelecer ações de aperfeiçoamento profissional, uma vez que as competências retratam o desempenho esperado do professor.

1. Competências

Profissionais
2. Ensino Médio

3. Desempenho

Docente 


\section{SUMÁRIO}

1. INTRODUÇÃO

1.1. Contextualização do Assunto e Formulação do Problema............................9

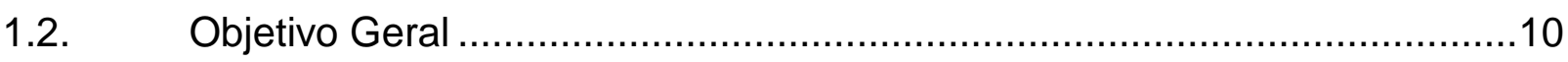

1.3. Objetivos Específicos ....................................................................

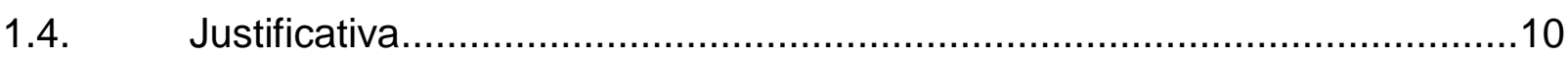

1.5. Metodologia (Métodos e Técnicas de Pesquisa):.....................................11

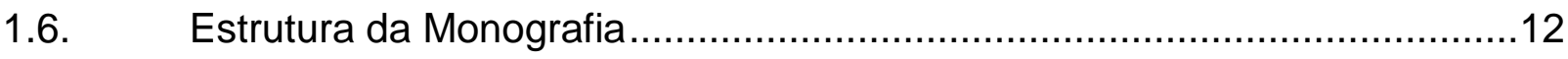

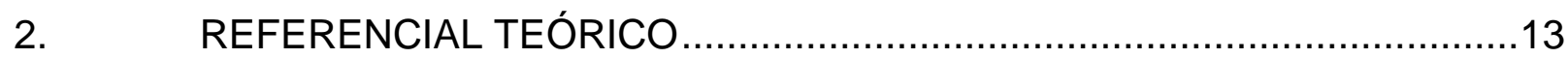

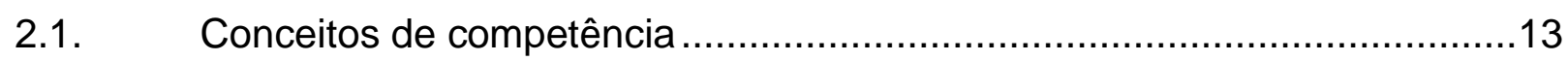

2.1.1. Classificação das competências ………….......................................17

2.1.2. O mapeamento de competências …………..................................18

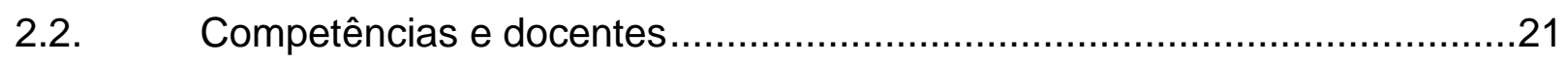

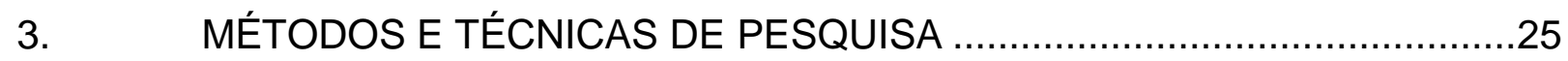

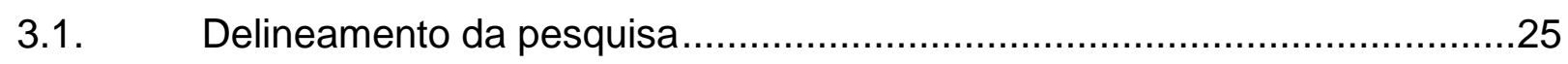

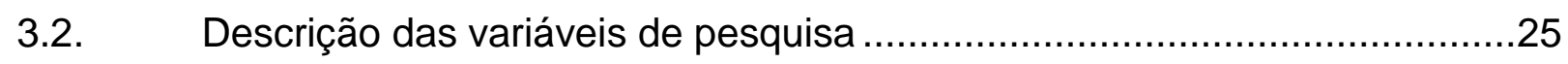

3.3. Caracterização da instituição de ensino.................................................26

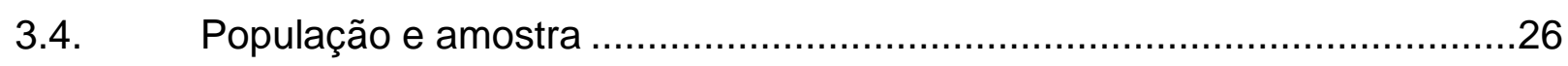

3.5. Caracterização dos instrumentos de pesquisa........................................27

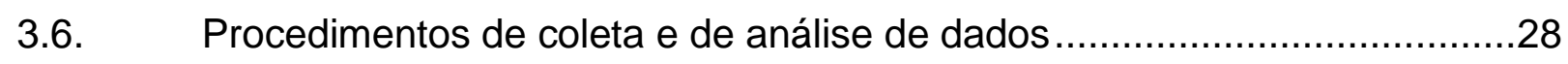

3.7. Período de realização da pesquisa .........................................................30

3.8. Comentários sobre o processo da coleta de dados ..................................30

4. APRESENTAÇÃO E DISCUSSÃO DOS RESULTADOS DA PESQUISA..32

4.1. Pesquisa Documental ...................................................................

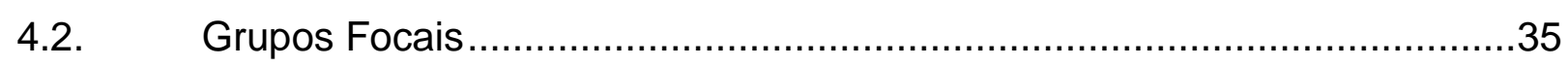

4.2.1. Competências de acordo com a percepção de alunos ...............................35

4.2.2. Competências de acordo com a percepção de gestores .............................38

4.2.3. Competências de acordo com a percepção de professores ........................41

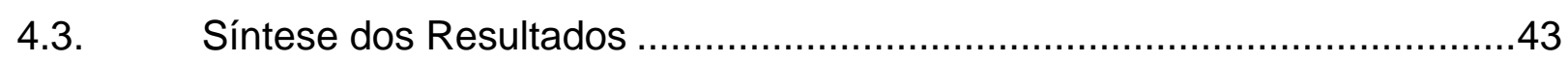

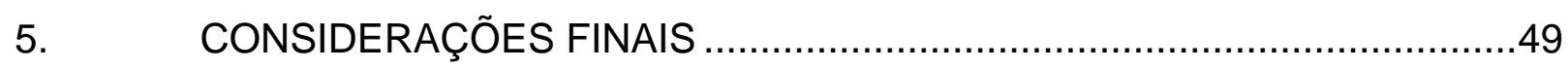

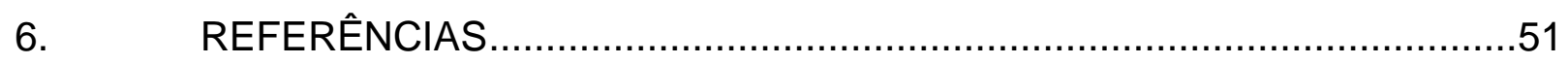

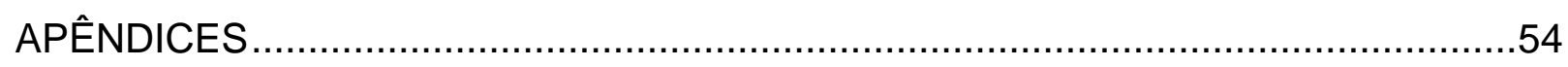

Apêndice A: Roteiro Grupo Focal .................................................................

Apêndice B: Carta-convite Professores ...........................................................55

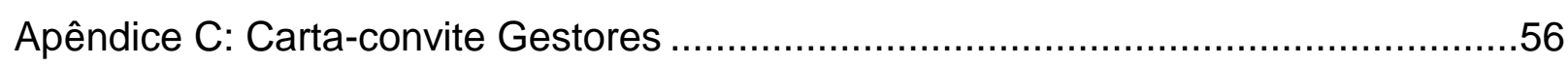

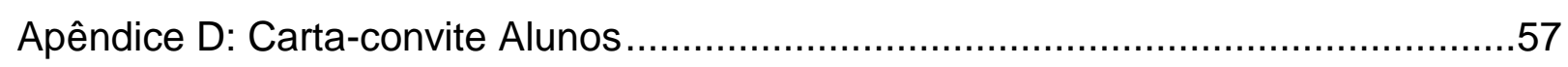




\section{LISTA DE FIGURAS}

Figura 1 - As três Dimensões da Competência. .14

Figura 2 - Competências como Fonte de Valor para o Indivíduo e para a Organização. 16

Figura 3 - Identificação do gap de competências. 18 


\section{LISTA DE QUADROS}

Quadro 1 - Exemplos de descrição de competências individuais sob a forma de referenciais de desempenho. 20

Quadro 2 - Exemplos de condições e critérios associados a competências .20

Quadro 3 - Competências da análise documental. .31

Quadro 4 - Competências na percepção dos alunos .35

Quadro 5 - Competências na percepção dos gestores. .38

Quadro 6 - Competências na percepção dos professores. .41

Quadro 7 - Síntese das competências. .43 


\section{INTRODUÇÃO}

Nesta seção será apresentada a contextualização assunto tema de estudo bem como a formulação do problema. Serão apresentados o objetivo geral e os específicos da pesquisa bem como a relevância do estudo e uma breve explicação da metodologia utilizada. Ao final, apresenta-se a estrutura na qual o trabalho está descrito.

\subsection{Contextualização do Assunto e Formulação do Problema}

As mudanças pelas quais o mundo do trabalho vem passando e a nova configuração da realidade torna o imprevisto mais cotidiano e rotineiro. Sendo assim para atender à realidade profissional que se insere, mutável e complexa, o trabalho não mais se baseia apenas no conjunto de tarefas do cargo, mas se torna a extensão da competência do indivíduo (FLEURY; FLEURY, 2001).

Tais mudanças requerem que as empresas tenham uma grande flexibilidade de forma a se manterem competitivas (HANASHIRO; NASSIF, 2006). Tendo em vista o fato de que hoje alguns elementos antes considerados importantes fatores de competitividade, como tecnologia, localização privilegiada, mão-de-obra barata, não são mais suficientes para garantir sucesso às empresas no atual cenário, as pessoas e suas competências passam a ser elementos-chave de diferenciação estratégica (PRAHALAD; HAMEL, 1995).

Uma vez que os funcionários são peças-chave deste processo de mudança, exige-se, portanto, que estes adquiram e desenvolvam rapidamente novos conhecimentos e habilidades (HANASHIRO; NASSIF, 2006).

Uma boa metáfora que pode explicitar a importância da competência é definida por Durand (1998 apud FLEURY; FLEURY, 2007):

Nos tempos medievais, os alquimistas procuravam transformar metais em ouro; hoje, os gerentes e as empresas procuram transformar recursos e ativos em lucro. Uma nova forma de alquimia é necessária às organizações. Vamos chamá-la de competência. (DURAND, 1998 apud FLEURY; FLEURY, 2007, p.32).

Baseando-se no pressuposto de que o domínio de certos recursos é determinante do desempenho superior de uma organização, a gestão de competências propõe-se a integrar e orientar esforços, sobretudo os relacionados à 
gestão de pessoas, visando desenvolver e sustentar competências consideradas fundamentais à consecução de objetivos organizacionais (PRAHALAD; HAMEL, 1990; DURAND, 1998 apud BRUNO-FARIA; BRANDÃO, 2003).

No caso das instituições de ensino, elas podem ser consideradas organizações diferenciadas, uma vez que necessitam identificar tais competências de seus profissionais a fim de contribuírem para a formação dos seus alunos, e dessa maneira atingirem seus objetivos e se manterem competitivas no mercado.

O currículo por competências, a avaliação do desempenho, a promoção dos professores por mérito, os conceitos de produtividade, eficiência e eficácia, entre outros, disseminam-se nas reformas educacionais em curso no mundo globalizado (DIAS; LOPES, 2003).

Dessa maneira, a fim de contribuir para o alcance de objetivos e adaptações às mudanças, procura-se responder à seguinte questão: "Quais as competências fundamentais aos professores do Colégio Marista de Brasília para que apresentem um desempenho de qualidade consoante com os objetivos institucionais?"

\subsection{Objetivo Geral}

Identificar as competências fundamentais para professores de uma instituição educacional de ensino médio.

\subsection{Objetivos Específicos}

a) Revisar as principais regulamentações que regem a educação básica e seus docentes.

b) Identificar os objetivos, principais valores e cultura da organização a ser pesquisada

c) Descrever as competências fundamentais aos professores do ensino médio de acordo com a percepção de alunos, professores e gestores de uma instituição educacional privada do Distrito Federal

\subsection{Justificativa}

Buscando atender às novas demandas exigidas pelo contexto que se insere, de transformações no âmbito social, econômico, cultural, as organizações buscam desenvolver, criar e inovar em todos os sentidos: seja em produtos, processos ou modelos de gestão, a fim de que possam melhorar continuamente seu desempenho (BRANDÃO; BORGES-ANDRADE, 2007). Considerando eficiência e eficácia 
variáveis do desempenho, as organizações parecem derivar, cada vez mais, de sua capacidade de desenvolver competências e de integrá-las em torno dos objetivos organizacionais (BRANDÃO; BAHRY, 2005)

A gestão por competências se insere entre os modelos gerenciais propostos para aprimorar o desempenho profissional e organizacional. Muitas empresas vêm utilizando modelos de gestão baseado em competências e desempenho a fim de desenvolver nos diferentes níveis da organização as competências que são necessárias para o alcance dos seus objetivos (CARBONE et al., 2005).

Considerando que as tendências de desenvolvimento econômico, social e cultural exigem esforços para satisfazer todas as necessidades humanas, em particular, as educacionais (BRASLAVSKI, 2001), as instituições de ensino se encaixam, portanto, em ambos os contextos, exigindo mudanças de caráter organizacional e educacional.

Cabe aqui ressaltar, portanto, a importância do professor como agente fundamental para o alcance destes objetivos e execução destas mudanças, e dessa maneira, a relevância de formá-los e desenvolvê-los de maneira adequada.

Do professor cobra-se a necessidade de formar alunos capacitados para enfrentar as exigências do mercado, sem, contudo, haver uma reflexão mais profunda sobre quais são e como estes professores desenvolvem sua competência (HANASHIRO; NASSIF, 2006, p. 46).

No processo de gestão por competências, a etapa de diagnóstico das competências é de fundamental importância, pois dela decorrem as ações de captação e desenvolvimento de competências, avaliação e retribuição (BRANDÃO; BAHRY, 2005).

Neste sentido, conhecer as competências fundamentais para os professores desta instituição é imprescindível para que se alcancem os objetivos da mesma, bem como esta possa se adequar às mudanças requeridas pelo mercado e melhor formar seus alunos

\subsection{Metodologia (Métodos e Técnicas de Pesquisa):}

Para identificação das competências foi utilizada pesquisa documental e realização de grupos focais com pessoas-chave de diferentes níveis da instituição de ensino. A pesquisa documental teve como principal objetivo compreender os principais valores, cultura e objetivos da Organização. Já os grupos focais visaram coletar a percepção dos principais atores do processo sobre as competências 
fundamentais. Após coletadas tais informações, a pesquisadora descreveu as competências de acordo com a percepção dos professores, alunos e gestores, além de descrever as competências identificadas na análise documental. As competências foram descritas sob a forma de referenciais de desempenho, conceito tratado por Guimarães, Bruno-Faria, Brandão (2006); Carbone et al. (2005); Santos (2001), ou seja, a competência é apresentada de forma a expressar comportamentos passíveis de observação no ambiente de trabalho e deve ser clara, a fim de que todas as pessoas compreendam a competência da mesma maneira.

\subsection{Estrutura da Monografia}

Para melhor compreensão do assunto a ser tratado pela pesquisa, serão abordados inicialmente os principais conceitos que cercam o tema da gestão por competências, que principalmente após fazer parte do vocabulário acadêmico e empresarial tomou diversas conotações. Serão apresentadas brevemente algumas diferenciações na classificação destas competências para a organização e por último alguns pontos importantes sobre os modelos de mapeamento de competências, que se relaciona com o objetivo principal do presente estudo.

Em seguida, serão apresentadas as principais mudanças pelas quais o ensino médio passa hoje, de onde e por que surgiram e como os professores se encaixam como atores deste processo de mudança, além de apresentar alguns estudos sobre competências docentes.

Posteriormente, será apresentado o detalhamento da metodologia que foi empregada no trabalho de forma a alcançar os objetivos propostos.

Por último, será exposta a análise e discussão dos dados obtidos pela pesquisa e as considerações finais. 


\section{REFERENCIAL TEÓRICO}

Este capítulo apresentará a revisão de literatura sobre os principais aspectos relacionados a competências: principais conceitos, classificações e mapeamento. Será abordado ainda questões relacionadas à educação básica no Brasil e seus docentes.

\subsection{Conceitos de competência}

Inicialmente, o termo competência era utilizado apenas no campo jurídico, caracterizando a capacidade de alguém ou alguma instituição de apreciar ou julgar determinadas questões. Por extensão, no campo social, o termo veio representar a capacidade de alguém de pronunciar-se em relação a determinado assunto e, mais tarde, passou a ser utilizado para qualificar o indivíduo capaz de realizar determinado trabalho (ISAMBERT-JAMATI, 1997 apud BRANDÃO; GUIMARÃES, 2001).

Já no campo do senso comum, o termo competência é utilizado para caracterizar determinado indivíduo que é capaz de realizar determinada tarefa. O seu antônimo traduz não somente a incapacidade do indivíduo para a realização de tal tarefa, mas possui também um sentido pejorativo, depreciativo (FLEURY; FLEURY, 2001).

Foi com a Revolução Industrial e o advento do taylorismo que o termo competência foi incorporado à linguagem organizacional, sendo utilizado para caracterizar aquele capaz de desempenhar eficientemente determinado papel (CARBONE et al., 2005).

A utilização freqüente do termo competência no campo organizacional fez com que este adquirisse diferentes conotações (GUIMARÃES; BRUNO-FARIA; BRANDÃO, 2006).

Para conceituar competência, Zarifian (2001) baseia-se na premissa de que em um ambiente mutável, não é possível considerar o trabalho como um conjunto de tarefas ou atividades predefinidas e estáticas. Sendo assim, competência significa tomar iniciativa e assumir responsabilidade, ir além das atividades prescritas, ser capaz de compreender e dominar novas situações no trabalho e ser reconhecido por isto.

Medef (1998 apud ZARIFIAN, 2001) define competência profissional como: 
A competência profissional é uma combinação de conhecimentos, de saberfazer, de experiências e comportamentos que se exerce em um contexto preciso. Ela é constatada quando de sua utilização em situação profissional a partir da qual é passível de validação. Compete então à empresa identificá-la, avaliá-la e fazê-la evoluir (MEDEF, 1998 apud ZARIFIAN, 2001, p. 66).

Segundo Le Boterf (2003), a competência é uma mistura de alguns aspectos fundamentais: o saber agir com pertinência, o saber mobilizar saberes e conhecimentos em um contexto profissional, integrar recursos, transferir conhecimento, saber aprender e aprender a aprender, envolver-se. Tudo isso deve ainda ser passível de reconhecimento pelo outro para que a competência exista socialmente.

Algumas pesquisas indicam que três elementos determinantes da competência (conhecimentos, habilidades e atitudes) possuem caráter complementar e interdependente, de forma que existe uma influência mútua entre eles (BRANDÃO; BORGES-ANDRADE, 2007).

A Figura 1 representa de forma visual a integração das três dimensões da competência citadas anteriormente:

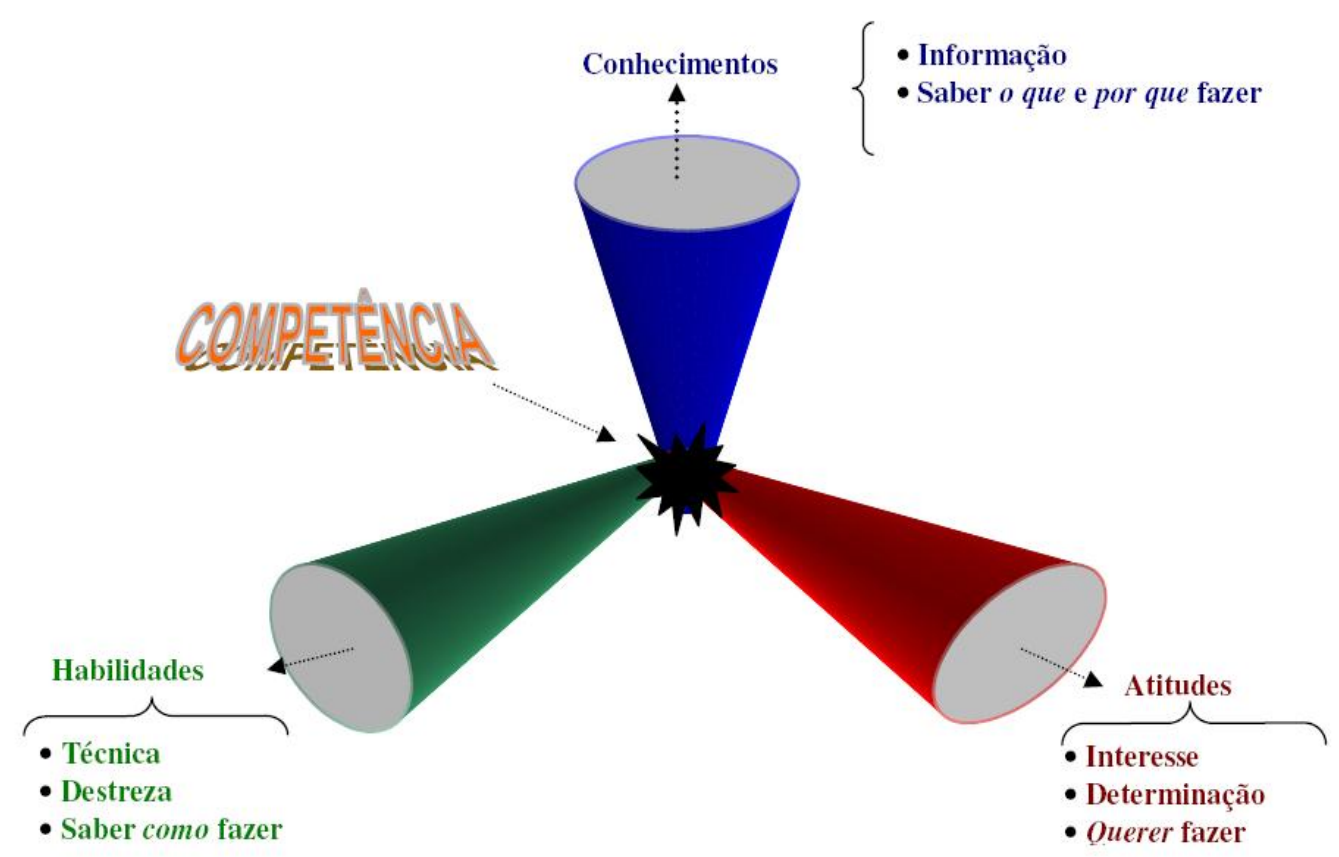

Figura 1- As três Dimensões da Competência

Fonte: Durand (1999 apud BRANDÃO e GUIMARÃES, 2001, p.10 , com adaptações)

A Figura 1 representa então, que a competência é formada por três dimensões e só pode ser caracterizada se apresentada todas elas. O conhecimento pode ser definido como um conjunto de informações absorvidas pelo individuo e que 
guiam um determinado comportamento. Já a habilidade pode ser caracterizada como a aplicação deste conhecimento, ou seja, a utilização produtiva deste. E por último, a atitude, diz respeito à vontade da pessoa, ou seja, o querer fazer, que determina sua conduta em relação aos outros, ao trabalho ou a situações. (CARBONE et al., 2005)

Para Ropé e Tanguy (1997 apud BRANDÃO; GUIMARÃES, 2001), um dos aspectos essenciais da competência é que esta não pode ser compreendida de forma separada da ação. Pode-se, portanto, falar-se que "não há competência senão em ato" (LE BOTERF, 2003), isto é, a competência não funciona apenas com um conjunto de saberes e habilidades.

As competências são reveladas, então, quando as pessoas agem frente às situações profissionais com as quais se defrontam (ZARIFIAN, 1999). Servem como ligação entre as condutas individuais e a estratégia da organização (CARBONE et al.,2005).

Segundo Sparrow e Bognanno (1994 apud BRANDÃO; GUIMARÃES, 2001) competências representam atitudes identificadas como relevantes para a obtenção de alto desempenho em um trabalho específico ao longo de uma carreira profissional ou no contexto de uma estratégia corporativa.

Dutra (2007) agrega ao conceito de competência, a "entrega". Além do conjunto de conhecimentos, habilidades e atitudes é necessário verificar o que se entrega ou o que se deseja entregar para a organização. A competência que é entregue agrega valor à organização permitindo que ela se mantenha competitiva.

No mundo do trabalho a palavra competência vem assumindo diversos significados, alguns mais ligados às características das pessoas e outros à tarefa (MCLAGAN, 1997 apud FLEURY; FLEURY, 2007). Assim competência pode ser definida como capacidade de a pessoa gerar resultados dentro dos objetivos estratégicos e organizacionais da empresa, podendo ser desenvolvida a partir do mapeamento do resultado esperado e do conjunto de conhecimentos, habilidades e atitudes necessários para o seu alcance (DUTRA; HIPÓLITO, 2000).

Entre os profissionais de recursos humanos, uma definição comumente utilizada é a seguinte: "conjunto de conhecimentos, habilidades, atitudes que afetam a maior parte do trabalho de uma pessoa, e que se relacionam com o desempenho no trabalho" (PARRY, 1996 apud FLEURY; FLEURY, 2007, p.27)

O conceito de competência é pensado como um conjunto de conhecimentos, habilidades e atitudes que justificam um alto desempenho, na medida em que há 
também um pressuposto de que os melhores desempenhos estão fundamentados na inteligência e na personalidade das pessoas; nessa abordagem considera-se competência, portanto, como um estoque de recursos que o indivíduo detém. A avaliação desta competência individual é feita, no entanto, em relação ao conjunto de tarefas do cargo ou posição ocupada pela pessoa. (FLEURY; FLEURY 2007)

A competência do individuo não se reduz a um conhecimento ou know-how específico. (FLEURY; FLEURY 2007). Competência então é definida como um "saber agir responsável e reconhecido, que implica mobilizar, integrar, transferir conhecimentos, recursos, habilidades que agreguem valor econômico à organização e valor social ao indivíduo" (FLEURY; FLEURY, 2007,p.30), conforme é evidenciado na Figura 2.

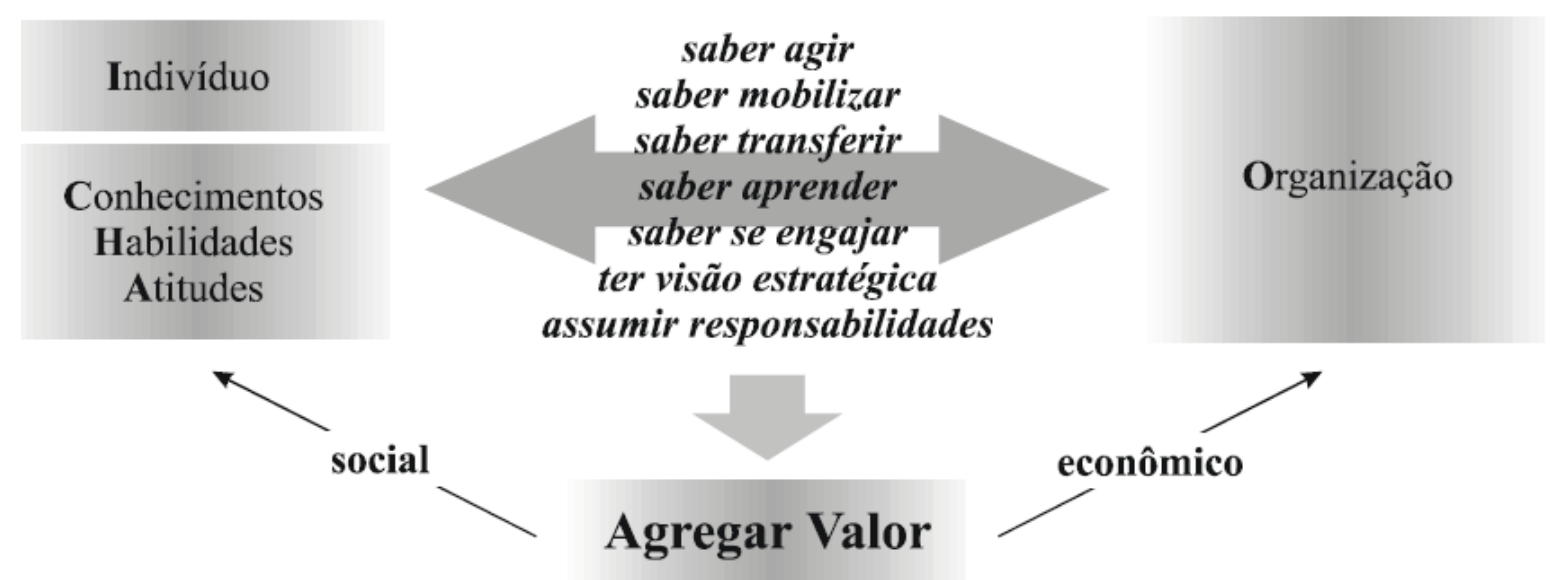

Figura 2- Competências como Fonte de Valor para o Indivíduo e para a Organização Fonte: Fleury e Fleury (2001, p.30)

Com base nos diversos conceitos apresentados por outros autores, Carbone et al. (2005) definem competência de modo a utilizar-se das concepções apresentadas. A competência então não é definida em termos apenas do conjunto de conhecimentos, habilidades e atitudes, mas também como desempenho apresentado decorrente da aplicação deste conjunto. Dessa forma, entendem-se competências humanas como "combinações sinérgicas de conhecimentos, habilidades e atitudes, expressas pelo desempenho profissional dentro de determinado contexto organizacional, que agregam valor a pessoas e organizações" (CARBONE et al., 2005, p.43). 
Tal definição apresenta maior aceitação tanto no mundo acadêmico quanto no organizacional a partir do momento que considera as diversas dimensões do trabalho e o desempenho dentro de um contexto organizacional (CARBONE et al., 2005)

\subsubsection{Classificação das competências}

Nos últimos anos, o tema competência entrou para a pauta das discussões acadêmicas e empresariais, associado a diferentes níveis de compreensão: no nível da pessoa (a competência do indivíduo), das organizações (as core competences) e dos países, segundo Fleury e Fleury (2007).

Já Guimarães, Bruno-Faria e Brandão (2006) caracterizam as competências no âmbito organizacional em dois níveis: o macronível e o micronível, este relacionado ao individuo e aquele às organizações.

Prahalad e Hamel (1990 apud BRANDÃO; GUIMARÃES, 2001) tratam do conceito no nível organizacional, referindo-se à competência como um conjunto de conhecimentos, habilidades, tecnologias, sistemas físicos e gerenciais inerentes a uma organização.

Alguns autores abrangem dentro da abordagem da competência outros níveis da organização. Zarifian (2001) sustenta que:

[...] em uma equipe ou rede de trabalho surge uma competência coletiva que é mais do que a soma das competências individuais. Isso se explica plenamente pelos efeitos de sinergia entre essas competências e pelas interações sociais ativadas no seio do grupo (ZARIFIAN, 2001, p.116).

Bruno-Faria e Brandão (2003) indicam a classificação das competências como profissionais ou humanas, que são as relacionadas a indivíduos ou a equipes de trabalho; e, organizacionais, aquelas inerentes à organização.

Ao utilizar essa tipologia para identificar as competências necessárias ao sucesso organizacional, torna-se possível gerenciá-las e direcionar os esforços e recursos da organização para a manutenção das competências essenciais, além de possibilitar o desenvolvimento das competências emergentes, permitindo a adoção de uma postura pró-ativa, tanto da organização quanto dos profissionais que dela fazem parte. (SPARROW; BOGNANNO, 1994 apud BRANDÃO; GUIMARÃES, 2001).

Le Boterf (2003) ressaltando que as competências coletivas emergem das cooperações, e sinergia estabelecidas entre as competências individuais dos 
componentes da equipe. Com esta competência coletiva, algumas competências perduram, mesmo com a perda de alguns profissionais.

A tipologia adotada para as competências depende da abordagem teórica utilizada ou ainda a finalidade prática que será atribuída ao conceito de competência (GUIMARÃES; BRUNO-FARIA; BRANDÃO, 2006).

\subsubsection{0 mapeamento de competências}

O mapeamento de competências tem como propósito identificar o gap ou lacuna de competências, ou seja, a diferença entre as competências que a organização necessita para a concretização de seus objetivos e aquelas que efetivamente possui. (IENAGA, 1998 apud BRANDÃO; BAHRY 2005). Logo, a gestão por competência visa essencialmente gerenciar esta lacuna existente, de modo a eliminá-la ou minimizá-la (CARBONE et al., 2006, p. 69).

A Figura 3 representa graficamente o que pode ser entendido como a lacuna de competências. Simboliza uma determinada organização em diferentes espaços de tempo e seus respectivos gaps, podendo ser aplicada às demais organizações.

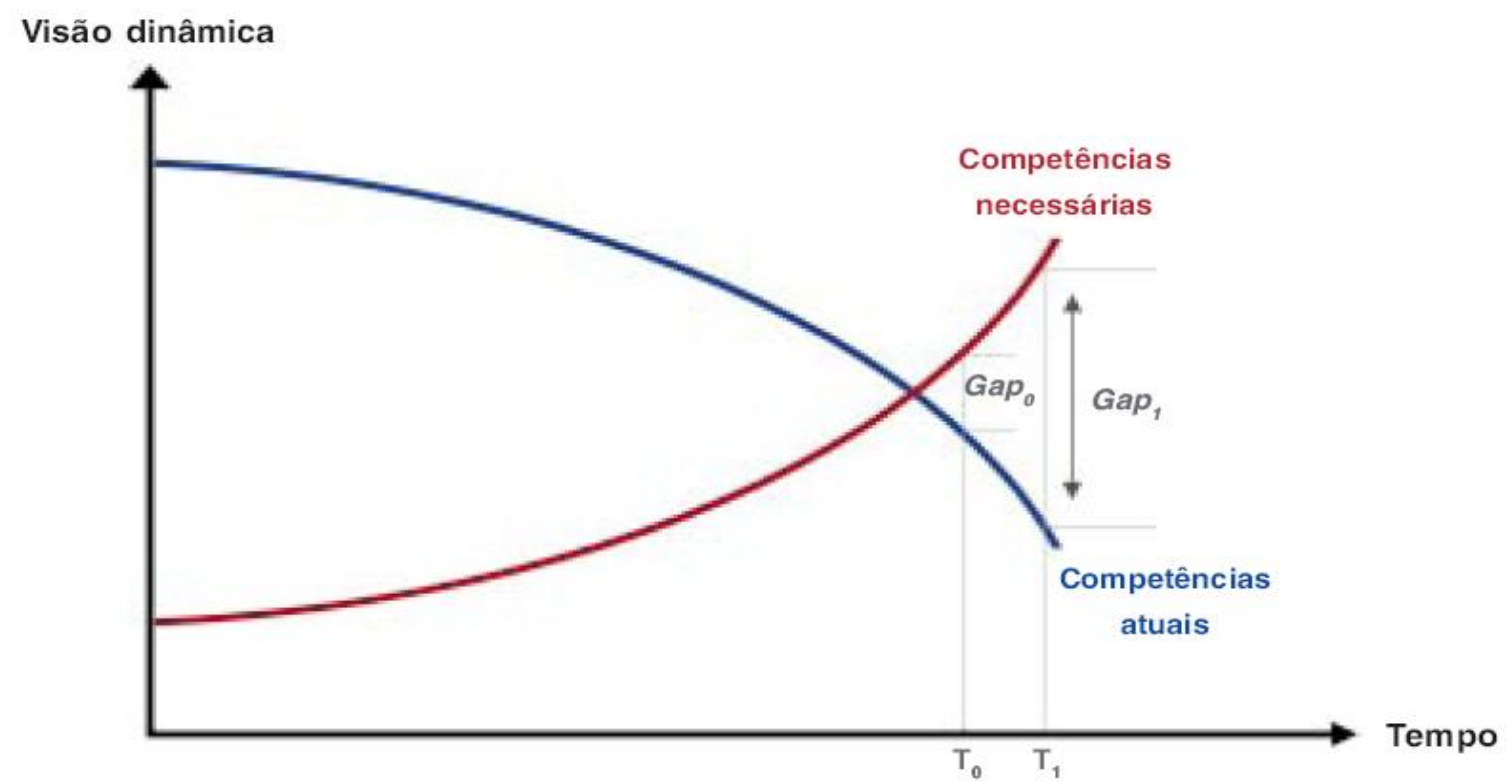

Figura 3 - Identificação do gap de competências Fonte: lenaga (1998 apud BRANDÃO; GUIMARAES, 2001, p. 11, com adaptações)

A realização de um diagnóstico criterioso de competências é fundamental uma vez que é insumo não apenas para definir estratégias organizacionais, mas também para subsidiar o processo decisório relacionado à gestão de pessoas em particular (GUIMARÃES; BRUNO-FARIA; BRANDÃO, 2006). 
Muitos métodos e técnicas podem ser utilizados para fazer este mapeamento. Este diagnóstico gerado não só identifica a lacuna de competências como permite também planejamento de ações de recrutamento, seleção e desenvolvimento profissional, por exemplo (BRANDÃO; BAHRY, 2005).

$O$ passo inicial desse processo consiste em identificar as competências (organizacionais e profissionais) necessárias à consecução dos objetivos da organização (CARBONE et al., 2005).

Essa identificação inicial pode ser realizada com uma pesquisa documental feita com documentos relativos à estratégia organizacional (CARBONE et al., 2005). A pesquisa documental é importante porque possibilita a compreensão da estratégia da organização e suas características fundamentais (GUIMARÃES; BRUNO-FARIA; BRANDÃO, 2006). Uma vez identificados os principais aspectos relacionados à estratégia da empresa, realiza-se coleta de dados com pessoas-chave da organização, para identificação das competências, a fim de que tais dados sejam cotejados com a análise documental, conforme proposto por Bruno-Faria e Brandão (2003).

O questionário é talvez a técnica mais utilizada para mapear competências relevantes para um contexto organizacional. A formatação desse instrumento de pesquisa geralmente requer a aplicação prévia de uma ou mais das técnicas de coleta de dados (análise documental, observação e entrevista), com o objetivo de identificar elementos para compor os itens do questionário (BRANDÃO; BAHRY, 2005).

No processo de identificação das competências um fator importante é a decisão de como serão descritas tais competências (GUIMARÃES; BRUNO-FARIA; BRANDÃO, 2006).

Não há uma maneira única de descrever as competências, alguns autores descrevem competências sob a forma de referenciais de desempenho, ou seja, a competência é apresentada de forma a expressar comportamentos passíveis de observação no ambiente de trabalho e deve ser clara, a fim de que todas as pessoas compreendam a competência da mesma maneira (GUIMARÃES; BRUNO-FARIA; BRANDÃO, 2006; CARBONE et al., 2005; SANTOS, 2001).

O Quadro 1 representa alguns exemplos de competências descritas como referenciais de desempenho. 


\begin{tabular}{|c|c|}
\hline Competência & Descrição (referenciais de desempenho) \\
\hline \multirow[t]{4}{*}{ Orientação para resultados } & Implementa ações para incrementar o volume de negócios. \\
\hline & $\begin{array}{l}\text { Avalia com precisão os custos e benefícios das oportunidades de } \\
\text { negócios. }\end{array}$ \\
\hline & $\begin{array}{l}\text { Utiliza indicadores de desempenho para avaliar os resultados } \\
\text { alcançados }\end{array}$ \\
\hline & Elabora planos para atingir as metas definidas \\
\hline \multirow[t]{4}{*}{ Trabalho em equipe } & Compartilha com seu grupo os desafios a enfrentar \\
\hline & $\begin{array}{l}\text { Mantém relacionamento interpessoal amigável e cordial com os } \\
\text { membros de sua equipe. }\end{array}$ \\
\hline & $\begin{array}{l}\text { Estimula a busca conjunta de soluções para os problemas } \\
\text { enfrentados pela equipe }\end{array}$ \\
\hline & Compartilha seus conhecimentos com os membros da equipe \\
\hline
\end{tabular}

Quadro 1: Exemplos de descrição de competências individuais sob a forma de referenciais de desempenho

Fonte: Santos (2001, p.27)

Dessa maneira, a descrição de uma competência deve representar um desempenho ou comportamento esperado, indicando o que o profissional deve ser capaz de fazer. Uma das maneiras de se descrever tais comportamentos é utilizando um verbo e um objeto de ação. Além destes dois aspectos pode-se acrescentar, sempre que possível e conveniente, uma condição e critério para a competência (BRANDÃO; BAHRY, 2005), conforme exemplo do Quadro 2.

\begin{tabular}{|l|l|l|}
\hline $\begin{array}{l}\text { Comportamento } \\
\text { (Verbo + Objeto da ação) }\end{array}$ & Critério & \multicolumn{1}{c|}{ Condição } \\
\hline Realiza análises financeiras & com acurácia & $\begin{array}{l}\text { utilizando diferentes } \\
\text { modelos para estimar o } \\
\text { retorno de investimentos }\end{array}$ \\
\hline $\begin{array}{l}\text { Atende aos cidadãos } \\
\text { (usuários do serviço público) }\end{array}$ & $\begin{array}{l}\text { com presteza e } \\
\text { cordialidade }\end{array}$ & $\begin{array}{l}\text { levando em considera- } \\
\text { ção as suas expectativas } \\
\text { e necessidades }\end{array}$ \\
\hline
\end{tabular}

Quadro 2: Exemplos de condições e critérios associados a competências.

Fonte: Brandão e Bahry (2005, p. 183)

Outros autores descrevem a competência individual em dimensões, sendo estas os "CHAs", ou, conhecimentos, habilidades e atitudes necessárias para que se apresente determinado resultado. (GUIMARÃES; BRUNO-FARIA; BRANDÃO, 2006). 
Discutidos alguns artigos científicos acerca do tema competências, é importante discutir a respeito da realidade educacional no Brasil de forma a avaliar o porquê da necessidade de se trabalhar competências dentro deste contexto organizacional.

\subsection{Competências e docentes}

Considerando os dinâmicos processos de globalização da economia e mundialização da cultura, observa-se uma forte influência dos interesses econômicos nas políticas educacionais (DIAS; LOPES, 2003).

Diante de tais mudanças, o ensino médio é aquele que tem acumulado maior defasagem em relação às suas origens históricas e capacidade de atendimento às demandas da sociedade (MARTINS, 2001).

A reforma do ensino médio surge, no Brasil, portanto, como um dos itens prioritários da política educacional do governo federal, justificada pela necessidade de se adequar esse nível de ensino às mudanças sociais, econômicas, políticas e culturais de âmbito mundial (MARTINS, 2000).

Segundo Ottone (1996 apud MARTINS, 2000), o atual modelo de ensino está mais ligado às sociedades industriais do século XIX que ao nascimento do século XXI. Dessa maneira segundo Martins (2000):

As mudanças em curso apontam para a necessidade de reforma na estrutura, na organização e na gestão dos sistemas de ensino; nos mecanismos de poder que ampliam ou diminuem a autonomia regional e local; nas políticas de currículo e na formação dos responsáveis pela sua implementação, os professores. (MARTINS, 2000, p. 73)

Segundo Carnoy e Castro (1996 apud MARTINS, 2000), a educação formal e seus principais protagonistas, os professores, encontram-se hoje no centro da discussão acerca da importância que a escolaridade adquire perante os atributos requisitados pela globalização da economia, da política e da cultura.

Pode-se considerar "a ausência de formação inicial adequada dos professores como um dos fatores mais dificultadores de mudança nas posturas sacralizadas de ensino" (MARTINS, 2001, p.78).

Sendo assim, uns dos principais pilares que os países em desenvolvimento devem focar em direção ao alcance de competitividade internacional são: políticas de formação inicial e continuada dos docentes e qualificação da mão-de-obra (CARNOY; CASTRO, 1996 apud MARTINS, 2000). 
Em resposta a essas expectativas, desde a década de 1980 os sistemas de ensino público e privado vêm passando por processos de reforma educacional, em âmbito estadual, local ou mesmo nas unidades escolares. Algumas dessas iniciativas de reforma são mais abrangentes e atingem todos os componentes do processo educativo; outras se dirigem apenas a alguns deles (MELLO, 2000).

Acreditando-se que alunos com bom desempenho escolar possuíam bons professores, desde o início do século surgiram pesquisas no campo da educação voltadas à identificação da competência do professor, intensificando-se especialmente nos anos de 1960 e 1970, quando passaram a visar, sobretudo, a medida dos comportamentos desejáveis no professor (DIAS; LOPES, 2003).

Segundo o artigo 35 da Lei de Diretrizes e Bases № 9.394, de 20 de dezembro de 1996 (BRASIL, 1996), o ensino médio é a etapa final da educação básica e tem como finalidades:

I - a consolidação e o aprofundamento dos conhecimentos adquiridos no ensino fundamental, possibilitando o prosseguimento de estudos;

II - a preparação básica para o trabalho e a cidadania do educando, para continuar aprendendo, de modo a ser capaz de se adaptar com flexibilidade a novas condições de ocupação ou aperfeiçoamento posteriores;

III - o aprimoramento do educando como pessoa humana, incluindo a formação ética e o desenvolvimento da autonomia intelectual e do pensamento crítico;

IV - a compreensão dos fundamentos científico-tecnológicos dos processos produtivos, relacionando a teoria com a prática, no ensino de cada disciplina.

Com a necessidade de novas demandas de formação de competências na educação básica, a formação inicial dos professores para atuarem nesta deve levar em conta os princípios pedagógicos estabelecidos nas normas curriculares nacionais: "a interdisciplinaridade, a transversalidade e a contextualização, e a integração de áreas em projetos de ensino, que constituem hoje mandados ou recomendações nacionais" (MELLO, 2000, p.102).

"As mudanças em curso na organização do trabalho deixam muitos educadores atônitos em relação ao perfil de habilidades e de competências". (MELLO, 1999, p.4). Com o advento da Internet os professores hoje devem compreender que não são mais a única fonte legítima de conhecimento para o aluno (MELLO, 2000). Porém "fortalece-se o papel que o professor sempre teve de ajudar o aluno a dar sentido às informações, avaliando, criticando, compreendendo, julgando a pertinência 
e aplicando-as na vida prática." (MELLO, 1999, p.4), como melhor explicitado na seguinte citação do próprio autor:

Isso terá cada vez mais impacto sobre a atividade docente. O professor não precisa ser a única fonte de conhecimentos para legitimar-se entre os alunos. Os conhecimentos podem vir da Internet, da televisão, do vizinho, da prática social, do trabalho. Mas o sentido que esses conhecimentos podem constituir é uma coisa que esse professor pode e deve trabalhar. E quem trabalha sentido trabalha linguagem; trabalha a língua e trabalha as demais linguagens: a linguagem do corpo, da música, das artes, da informática, como recursos para constituir sentido, que permitam à pessoa navegar na enxurrada de informações sem afogar-se. (MELLO, 1999, p.4)

Como citado por Nunes (2001, p.10), a partir da década de 1990, foram iniciadas pesquisas que "buscam resgatar o papel do professor, destacando a importância de se pensar a formação numa abordagem que vá além da acadêmica, envolvendo o desenvolvimento pessoal, profissional e organizacional da profissão docente".

Therrien (1995 apud NUNES, 2001) salienta o quanto os estudos sobre a formação do professor ainda persistem em uma dissociação entre a formação e a prática cotidiana, não enfatizando a questão dos saberes que são mobilizados na prática, ou seja, os saberes da experiência.

\footnotetext{
Estudos [...] têm destacado a importância do desenvolvimento de pesquisas, em nossa realidade, que busquem identificar e analisar os saberes docentes numa perspectiva de contribuir para a ampliação do campo e para a implementação de políticas que envolvam a questão da formação do professor, a partir da ótica dos próprios sujeitos envolvidos (NUNES, 2001, p.3)
}

Essas novas características que vêm sido implantadas e desenvolvidas no ensino e conseqüentemente na formação dos professores têm sido alavancas para um esforço de construir um repertório de conhecimentos e definir competências para a formação e a prática do magistério (NUNES, 2001).

É devido a isso, portanto, que se busca identificar quais são as competências fundamentais para atender a essas demandas entre outras próprias à organização.

Em estudo destinado a identificar competências gerenciais necessárias aos professores-gerentes que atuam em pró-reitorias, Campos (2008) realizou pesquisa qualitativa com 11 professores com experiência gerencial como dirigentes de nível estratégico. Identificou 11 categorias de competências: resolver problemas por meio da criatividade, compartilhar dos interesses institucionais, induzir o envolvimento dos outros, conhecer a estrutura organizacional, ter experiência gerencial na Instituição, 
saber dividir o tempo com atividades da docência, comunicar às partes interessadas as decisões dos Conselhos Superiores, ter capacidade política, planejar as atividades do órgão que administra, ter iniciativa para tomar decisões e saber administrar recursos.

Já Perrenoud (2000) apresenta 10 domínios de competências reconhecidas como prioritárias na formação contínua das professoras e professores do ensino fundamental, sendo elas: Organizar e dirigir situações de aprendizagem, administrar a progressão das aprendizagens, conceber e fazer evoluir os dispositivos de diferenciação, envolver os alunos em sua aprendizagem e seu trabalho, trabalhar em equipe, participar da administração da escola, informar e envolver os pais, utilizar novas tecnologias, enfrentar os deveres e os dilemas éticos da profissão, administrar sua própria formação contínua. Tais competências são detalhadas ainda em competências específicas para se trabalhar a formação contínua do professor.

O próximo capítulo trará mais detalhes sobre a pesquisa realizada a fim de se identificar quais são as competências fundamentais para professores do Ensino Médio de uma Instituição privada. 


\section{MÉTODOS E TÉCNICAS DE PESQUISA}

\subsection{Delineamento da pesquisa}

A pesquisa teve caráter qualitativo. Para caracterizar o tipo da pesquisa recorrese à taxonomia apresentada por Vergara (2005) que a qualifica em dois critérios básicos: quanto aos fins e quanto aos meios.

Quanto aos fins, a pesquisa foi descritiva, pois "expõe características de determinada população ou determinado fenômeno" (VERGARA, 2005, p.47). No caso as competências foram descritas a partir da percepção de diferentes atores.

Quanto aos meios de investigação, a pesquisa foi documental e de campo. Documental, pois analisou diversos documentos internos à Instituição. A pesquisa foi também de campo, pois foi "realizada no local onde ocorre ou ocorreu um fenômeno ou que dispõe de elementos para explicá-lo" (VERGARA, 2005, p.47).

Além da pesquisa documental nos arquivos internos ao Colégio Marista, como projeto pedagógico e documento com a descrição do cargo de professor, a técnica principal de coleta de dados empregada no estudo foi a de grupos focais com representantes de diferentes níveis da Instituição.

\subsection{Descrição das variáveis de pesquisa}

Embora a pesquisa qualitativa não tenha como objetivo delimitar variáveis, a fim de estabelecer correlações típicas dos desenhos de pesquisa quantitativos, destacase que a variável principal estudada (que poderia ser vista como uma variável dependente em um estudo quantitativo) foi "competências fundamentais aos docentes de ensino médio de uma instituição privada de ensino". Com base na mesma analogia aos estudos quantitativos, as diferentes percepções dos atores que fazem parte da referida Instituição, corresponderiam a variáveis independentes do estudo. Entretanto, cabe ressaltar, segundo Creswell (2007, p. 35), que a técnica qualitativa focaliza os "significados múltiplos das experiências individuais", enquanto que a pesquisa quantitativa volta-se para o "raciocínio de causa e efeito, redução de variáveis específicas", dentre outros aspectos. 


\subsection{Caracterização da instituição de ensino}

Conforme pesquisa documental preliminar no site ${ }^{1}$ da Instituição de ensino constatou-se que o Colégio Marista de Brasília é uma das mais antigas instituições de ensino médio do Distrito Federal, tendo sido fundado em 1962. É uma instituição de ensino católica que busca oferecer uma educação baseada nos valores cristãos e na construção de conteúdos essenciais para o exercício de uma cidadania ética, consciente e crítica. Os compromissos da Instituição são a evangelização e a excelência acadêmica.

Atualmente, o Colégio Marista de Brasília atende alunos da Educação Infantil, do Ensino Fundamental e do Ensino Médio. A Educação Infantil e o Ensino Fundamental fazem parte de uma mesma unidade na 609 sul, e o Ensino Médio, objeto de estudo, é uma unidade separada na 615 sul. Todas essas unidades fazem parte da Província Marista do Brasil Centro-Sul, que além do Distrito Federal abrange os estados de Mato Grosso do Sul, São Paulo, Paraná e Santa Catarina.

O Ensino Médio, também conhecido como Maristão, foi inaugurado em 1974 e conta com 1.508 alunos e cerca de 70 professores nas mais diversas áreas de conhecimento.

\subsection{População e amostra}

Optou-se por estudar o Maristão que, além dos 1.508 alunos e 70 professores, contava com mais de 10 pessoas na equipe de direção da escola na ocasião da pesquisa.

Os estudantes tinham idade entre 15 e 18 anos, em sua maioria de classe média. Os professores possuíam formação em áreas distintas de conhecimentos, como Física, Matemática e Biologia. Já os gestores da empres são pessoas de diferentes formações, porém todos possuem algum tipo de especialização, mestrado ou doutorado na área pedagógica.

A escolha dos participantes foi dada por acessibilidade, ou seja, "seleciona os elementos pela facilidade de acesso a eles" (VERGARA, 2005, p. 51.)

Dessa maneira, cinco professores participaram do grupo focal, sendo quatro do sexo masculino e uma do sexo feminino. Deste grupo de cinco professores, dois possuíam menos de 10 anos de escola e os outros três possuíam mais de 10 anos e

\footnotetext{
${ }^{1}$ www.marista.org.br
} 
menos que 15 anos de trabalho no colégio. As áreas de especialização desses participantes foram: Biologia, Geografia, Inglês, Ensino Religioso e Artes Visuais.

No grupo focal dos gestores, participaram da pesquisa dois diretores, quatro assessores, duas assistentes e uma supervisora. Dessa maneira, o grupo foi composto por nove pessoas, sendo cinco do sexo feminino e quatro do sexo masculino. Deste grupo, três trabalham há menos de um ano no colégio, três há menos de 10 anos e três trabalham há 10 anos ou mais no colégio.

No caso dos alunos, estes foram divididos em dois grupos focais devido ao número de participantes. Porém, uma vez que a pesquisa visava analisar as percepções de alunos, professores e gestores, nos grupos focais de alunos os resultados aparecem como um só. Dessa maneira a amostra de alunos foi de 12 , sendo todos alunos do segundo ano do ensino médio e com idade de 16 anos. Seis são do sexo feminino e seis do sexo masculino. Todos estes alunos estudavam no Marista-Ensino Médio desde o primeiro ano sendo que cinco deles não estudaram no Marista - Ensino Fundamental, e dos que estudaram, três estudavam no colégio há menos de 10 anos e os outros quatro estudavam no colégio há 10 anos ou mais.

A amostra de documentos para a pesquisa documental foi composta pelo projeto pedagógico da escola, pela Missão Educativa Marista e pela descrição do cargo de professor.

\subsection{Caracterização dos instrumentos de pesquisa}

$\mathrm{Na}$ coleta de dados documental os principais pontos reunidos foram os principais valores da Instituição, pontos que caracterizam sua cultura, seus principais objetivos, e exigências relacionadas ao cargo de professor.

Já a pesquisa de campo foi realizada por meio de grupo focal e foi utilizado um roteiro semi-estruturado (Apêndice A) para mediar a discussão. $O$ roteiro foi uma forma de orientar e estimular a discussão no grupo e foi utilizado com flexibilidade ajustado ao longo do trabalho (GATTI, 2005) de acordo com o processo de interação do grupo.

O roteiro e a posterior descrição das competências foram baseados nos pressupostos apresentados por Guimarães, Bruno-Faria e Brandão (2006); Carbone et al. (2005); Santos (2001) que descrevem competências sob a forma de referenciais de desempenho, ou seja, a competência retrata comportamentos passíveis de observação no ambiente de trabalho. 


\subsection{Procedimentos de coleta e de análise de dados}

Em relação aos documentos pesquisados, todos eles foram fornecidos pelo Diretor Educacional do Colégio Marista.

No caso dos grupos focais, eles ocorreram em quatro momentos distintos, conforme a disponibilidade dos diferentes participantes do estudo.

Foram realizados dois grupos focais com alunos, ou seja, foram formados dois grupos distintos compostos por alunos, sendo cada um deles com seis alunos. Um grupo focal foi realizado com os gestores do colégio, contando com a participação de nove deles, e por ultimo, foi realizado um grupo focal com professores, onde participaram cinco coordenadores de área.

Para ser possível abordar as questões com maior profundidade, Gatti (2005) sugere que os grupos focais tenham entre seis e 12 integrantes, dessa maneira, os grupos contavam com este limite, apenas no caso dos professores não foi possível estabelecer o limite mínimo devido à pouca aderência destes à pesquisa.

Os grupos focais foram previamente agendados e aconteceram no próprio espaço físico do Colégio Marista, em salas de reunião que possuíam uma mesa e cadeiras dispostas ao seu redor. Tanto os dois grupos de alunos como o de gestores tiveram duração de uma hora, considerando-se as informações iniciais e finais da pesquisadora. O grupo de professores teve duração de apenas quarenta minutos devido à restrição de horário do grupo.

Inicialmente, para a realização do grupo focal, foi enviada uma carta convite aos professores e os primeiros interessados que respondessem ao convite fariam parte do grupo, dentro do limite de pessoas sugerido que será explicitado adiante. Porém, por incompatibilidade de horário dos interessados, foi preciso contar com professores que possuíssem horários em comum. Desta maneira, o grupo focal foi realizado com os coordenadores de área, que já possuíam um horário disponível em comum toda semana; ainda assim alguns deles não estiveram presentes no momento do grupo focal.

No caso dos gestores, também foi enviada uma carta convite, porém, por determinação do Diretor Educacional, todos participaram do grupo focal. Já com os alunos, devido ao grande número deles, estes foram escolhidos por um representante do colégio, que convidou alunos que mais tinham ligação com atividades extracurriculares e, dessa maneira, estariam mais comprometidos com os objetivos 
propostos. Foi enviada uma carta-convite também a esses alunos e 12 deles aceitaram participar.

Os grupos focais foram mediados pela pesquisadora que utilizou dois gravadores, sendo um mp3 e um mp4, para melhor registrar as informações e facilitar o momento de análise dos dados.

Para aplicação do roteiro semi-estruturado foram seguidas algumas etapas fundamentais, sugeridas por Gatti (2005). Primeiramente, foi feita uma breve apresentação do moderador. Após esta etapa, foram apresentados os objetivos do grupo focal, bem como os principais objetivos da pesquisa. Em seguida, foi exposto como seria a forma de registro do trabalho e solicitou-se a autorização para gravação em áudio; nenhum dos participantes dos grupos foi contrário à gravação. Foi dada ênfase na garantia do sigilo quanto à identificação dos participantes. A pesquisadora enfatizou também a importância da participação de todos e solicitou que o foco da discussão se concentrasse no que deve ser apresentado pelo professor, e que evitassem queixas sobre os atuais professores.

Considerando que para iniciar o tema é importante que se faça um "aquecimento" com os participantes (GATTI, 2005), foi solicitado aos mesmos que fizessem um comentário geral sobre uma pergunta específica, e logo em seguida, deu-se início à discussão sobre o tema central do estudo. Ao longo da realização dos grupos, apenas algumas perguntas foram acrescidas de forma a melhor compreender a fala do indivíduo para que não ocorresse juízo de valor da pesquisadora. Dessa maneira perguntas como: "O que você entende por autoridade? O que significa um ambiente agradável? Explique melhor o que significa afetividade na sua opinião?" foram acrescidas de forma a contribuir para a análise do conteúdo.

Ao final do grupo, foram coletadas algumas informações pessoais dos participantes como nome, sexo, tempo de escola, série e idade (no caso dos alunos), titulação (no caso de professores e gestores) e cargo (no caso de gestores). 0 moderador ao final do grupo questionou se alguém desejava registrar mais algum comentário e colocou-se à disposição para quem quisesse conversar particularmente com o moderador, porém não houve maiores interessados. Feito isso, foi realizado um breve agradecimento pela colaboração e disponibilidade dos participantes.

Para realizar a análise do conteúdo dos grupos focais, o conteúdo das gravações foi transcrito de forma a facilitar o trabalho com as informações coletadas. 
Dessa maneira, obteve-se cerca de quatro horas de gravação transcritas que geraram um total de vinte e oito páginas de falas para que fossem extraídas competências fundamentais ao professores.

Depois de transcritos os grupos focais, estas foram analisadas individualmente. Primeiro foi realizada a análise das competências obtidas com os do grupo de alunos, seguida dos gestores e professores. A primeira etapa realizada foi a pré-análise (FRANCO,2008), que buscava uma leitura inicial, sem muito comprometimento com a descrição das competências. Feito isso, as falas foram agrupadas pela semelhança, de forma a caracterizar as competências. Agrupadas essas falas, a pesquisadora iniciou a descrição de cada uma das competências, de acordo com cada um dos grupos (alunos, professores, gestores).

As competências prontas passaram por uma análise de juízes (especialistas no tema competências profissionais), que no caso foi a orientadora da monografia que validou as mesmas, a fim de garantir que os itens expressam competências de acordo com a opção teórica.

Como já citado, as competências foram descritas de acordo com o conceito de referenciais de desempenho apresentado por Guimarães, Bruno-Faria, Brandão (2006), Carbone et al. (2005), Santos (2001) de forma que a competência expressa comportamentos passíveis de observação no ambiente de trabalho.

\subsection{Período de realização da pesquisa}

A pesquisa foi realizada durante a segunda quinzena de maio e primeira semana de junho do ano de dois mil e nove, período este definido previamente de forma que os grupos focais pudessem ser agendados com antecedência, sem interferir na dinâmica do colégio.

\subsection{Comentários sobre o processo da coleta de dados}

O processo de coleta de dados se deu por meio de análise documental e grupos focais. A necessidade de um horário em comum entre muitos participantes dificultou 0 agendamento dos grupos focais. Notou-se durante os grupos focais que os alunos se mostraram muito entusiasmados em contribuir com a pesquisa. Os gestores e docentes também contribuíram com diferentes percepções. As falas dos sujeitos foram gravadas e transcritas e posteriormente agrupadas por similaridade. Para a realização de um grupo focal de qualidade, que pudesse ser insumo suficiente para 
as descrições, a pesquisadora seguiu algumas recomendações sugeridas por Gatti (2005). No caso dos documentos, houve a preocupação de identificar aqueles que melhor ajudariam a pesquisadora a compreender os objetivos, valores e cultura do Colégio. 


\section{APRESENTAÇÃO E DISCUSSÃO DOS RESULTADOS DA PESQUISA}

Para a exposição dos principais resultados da pesquisa, serão apresentados quadros com a descrição das competências e alguns exemplos de falas que possibilitaram a descrição de tais competências. Primeiramente serão apresentados os resultados da pesquisa documental e em seguida, os resultados dos grupos focais na percepção dos alunos, gestores e professores. Ao final haverá um quadro síntese com as competências identificadas na pesquisa que retratam as competências fundamentais aos docentes do Ensino Médio.

As competências são apresentadas sob forma de referenciais de desempenho (GUIMARÃES; BRUNO-FARIA; BRANDÃO, 2006; CARBONE et al., 2005; SANTOS, 2001), representando comportamentos observáveis no ambiente de trabalho, conforme opção teórica. As competências descritas sob referenciais de desempenho seguiram o formato sugerido por Brandão e Bahry (2005) segundo o qual se utiliza um verbo de ação (neste caso o verbo é utilizado no presente) além de algumas das competências apresentarem ainda critério e condição a fim de deixá-las mais claras.

\subsection{Pesquisa Documental}

As principais competências identificadas na análise documental foram coletadas a partir de informações sobre os fundamentos norteadores da prática educativa, da missão e objetivos institucionais e das funções e responsabilidades do cargo de professor.

O Quadro 3 apresenta as competências identificadas por meio da análise documental:

\begin{tabular}{|l|l|}
\hline Competências & Constatações \\
\hline $\begin{array}{c}1 \text { - Abre espaço para o diálogo e } \\
\text { estimula a participação dos } \\
\text { alunos }\end{array}$ & "A pedagogia da presença, marcada pela escuta e pelo diálogo" \\
\hline
\end{tabular}


2 - Apresenta experiências vividas e ressalta posturas condizentes com os valores da instituição durante os momentos de interação com os alunos, a fim de contribuir para a formação integral do adolescente.

3 - Cumpre prazos de entrega dos compromissos assumidos

4 - Elogia os alunos de modo a valorizar seu empenho e dedicação e estimulando-o a vencer as dificuldades

5 - Fornece orientações aos alunos para realizarem análise crítica nos seus momentos de estudo

6 - Mantêm a disciplina em sala de forma respeitosa, proporcionando um ambiente favorável ao estudo

7 - Organiza atividades diferenciadas a fim de atender as dificuldades de aprendizagem dos alunos

8 - Orienta individualmente os alunos no seu cotidiano escolar, nas atividades de estudo de meio e nas atividades culturais

9 - Participa de atividades obrigatórias (reunião de professores, palestras, etc) de

formação continuada com empenho e dedicação

10 - Participa, de forma

ativa, de atividades extracurriculares oferecidas pela escola

11 - Planeja as aulas

distribuindo as atividades de modo a facilitar o processo de ensino-aprendizagem
"A missão do professor marista é articular conhecimentos diversos e experiências pessoais construídos desde sua formação inicial para realizar uma prática educativa condizente com os valores estabelecidos pelas pedagogias marista"

"O professor precisa manter-se atualizado em relação às propostas do Instituto marista"

"..deve desenvolver processos de ensino-aprendizagem alinhados às diretrizes pastorais, orientações da direção"

"Acompanhar e orientar a formação humana-crista de seus alunos (...) constituindo-se como presença e exemplo de vida segundo a proposta Marista de evangelização"

"Promove a formação integral do adolescente"

Ter pontualidade no atendimento aos compromissos da unidade escolar (...) conforme contrato de trabalho estabelecido

Ter assiduidade e prever em tempo hábil as faltas programadas, bem como as atividades a serem desenvolvidas pelos alunos.

"Possui um olhar amoroso para os alunos, favorecendo assim a auto-estima e autoconfiança de cada um'

"Estimula o aluno a problematizar e construir conhecimentos"

"Construir com o aluno espírito investigativo e de pesquisa a fim de vinculá-lo a uma sociedade em constante transformação..."

As atribuições do professor: coordenação e monitoramento dos alunos, individualmente ou em grupos

Controle da disciplina e harmonia da turma

"Favorecer ambiente de convivência harmônica baseado no respeito mútuo"

Identificar dificuldades de aprendizagem dos alunos, para que possam ser organizadas atividades que promovam sua superação

Acompanhar e orientar individualmente os alunos no seu cotidiano escolar,

nas atividades de estudo de meio e nas atividades culturais

Colaborar com a orientação do aluno nas diversas atividades previstas no calendário escolar

"Participa das atividades obrigatórias de formação continuada (reunião de professores, palestras, etc.) com empenho e dedicação

"Tentar estar presentes em seminários, encontros culturais, cursos de aperfeiçoamento, grupos de estudos, que constam no calendário escolar"

As atribuições do professor: planejamento das atividades didáticas.. 


\begin{tabular}{|c|c|}
\hline $\begin{array}{l}12 \text { - Realiza pesquisas de } \\
\text { forma a manter-se } \\
\text { atualizado em relação à sua } \\
\text { área e aos avanços } \\
\text { científicos e tecnológicos }\end{array}$ & $\begin{array}{l}\text { Na instituição Marista o professor necessita manter-se } \\
\text { continuamente atualizado em relação à sua área especifica de } \\
\text { conhecimento e em relação aos avanços científicos e tecnológicos }\end{array}$ \\
\hline $\begin{array}{l}13 \text { - Relaciona-se de forma } \\
\text { cordial e respeitosa com } \\
\text { alunos, professores, } \\
\text { familiares e demais } \\
\text { profissionais do colégio }\end{array}$ & $\begin{array}{l}\text { "Mediar as relações interpessoais:aluno/professor, aluno/família, } \\
\text { aluno/aluno, família/escola, visando o estabelecimento de um clima } \\
\text { favorável à aprendizagem" } \\
\text { "Oferece educação de qualidade sem distinção de cor, sexo, } \\
\text { convicção religiosa ou classe social" } \\
\text { "Pedagogia marcada pela conquista da confiança dos educandos } \\
\text { num relacionamento baseado no respeito e no amor" }\end{array}$ \\
\hline
\end{tabular}

Quadro 3: Competências derivadas da análise documental

As competências extraídas dos documentos, em sua maioria, estão ligadas aos valores da Escola e sua essência católica e evangelizadora. Há uma ênfase na questão da "educação pelo amor" e na transmissão de valores e participação na formação do jovem. Tais características podem ser apresentadas a partir de diferentes desempenhos, ou seja, o professor demonstra seu amor, afeto e preocupação a partir de determinadas posturas, como, por exemplo, pelas competências de número 1, 2, 4 e 13.

Outras competências expressam responsabilidades do professor, do ponto de vista da Instituição escolar, como por exemplo, as competências de número 3, 8, 9,10, 11.

Existem competências que descrevem também o comportamento que deve ser apresentado pelo professor em relação às suas práticas de ensino, como por exemplo: "Abre espaço para o diálogo e estimula a participação dos alunos"; "Realiza pesquisas de forma a manter-se atualizado em relação à sua área e aos avanços científicos e tecnológicos"; "Fornece orientações aos alunos para realizarem análise crítica nos seus momentos de estudo"; "Mantém a disciplina em sala de forma respeitosa, contribuindo para um ambiente favorável ao estudo"; "Organiza atividades diferenciadas a fim de atender as dificuldades de aprendizagem dos alunos"; "Planeja as aulas distribuindo as atividades de modo a facilitar o processo de ensinoaprendizagem".

A seguir serão apresentadas as competências extraídas dos grupos focais. 


\subsection{Grupos Focais}

Inicialmente, os grupos focais permitiram a identificação de diversas competências. Os resultados serão apresentados de acordo com os diferentes atores participantes da pesquisa.

\subsubsection{Competências de acordo com a percepção de alunos}

Os alunos foram os que mais demonstraram entusiasmo e motivação para descrever o que consideravam importante para o professor apresentar um desempenho de qualidade, o Quadro 3 apresenta tais resultados.

\begin{tabular}{|c|c|}
\hline Competência & Falas \\
\hline $\begin{array}{c}1 \text { - Abre espaço para o } \\
\text { diálogo } \\
\text { e estimula a participação } \\
\text { dos alunos }\end{array}$ & $\begin{array}{l}\text { "Só que a partir do momento que precisa realmente focar e o } \\
\text { professor fala isso, a turma respeita, isso pra mim é autoridade e não } \\
\text { monopolizar a aula e ninguém fala" } \\
\text { "A aula inclusive é muito melhor quando a turma participa, as } \\
\text { pessoas aprendem mais, mas assim a ultima palavra pra mim tem } \\
\text { que ser do professor." }\end{array}$ \\
\hline $\begin{array}{l}2 \text { - Apresenta experiências } \\
\text { vividas e ressalta posturas } \\
\text { condizentes com os valores } \\
\text { da instituição durante os } \\
\text { momentos de interação com } \\
\text { os alunos, a fim de contribuir } \\
\text { para a formação integral do } \\
\text { adolescente. }\end{array}$ & $\begin{array}{l}\text { "Acho que o professor pode pensar no ser humano, no cidadão, não } \\
\text { só aluno" } \\
\text { "Essa questão de formação é super importante." } \\
\text { "Professor de física pode dar aula de assuntos sociais, é importante, } \\
\text { você ta aqui pra dar aula, mas não só no campo acadêmico, } \\
\text { professor passou por muitas situações que a gente não passou. } \\
\text { Então cara, se o professor fala tal coisa e a gente "caraca é verdade", } \\
\text { aquilo pode mudar a vida de uma pessoa." } \\
\text { Acho que o papel do professor é a formação do aluno, enfrentar a } \\
\text { vida, formar o caráter, é ser educador." }\end{array}$ \\
\hline $\begin{array}{c}3 \text { - Apresenta o conteúdo da } \\
\text { disciplina de forma clara e } \\
\text { objetiva }\end{array}$ & $\begin{array}{l}\text { "Também tem que dominar a matéria, tem que ta com a matéria } \\
\text { no ponto assim pra passar claramente" } \\
\text { "Ele tem que ta apresentando que sabe o que ta falando e falar com } \\
\text { clareza." } \\
\text { "O professor deve ser capaz de abordar todos os aspectos de um } \\
\text { conteúdo" }\end{array}$ \\
\hline $\begin{array}{l}4 \text { - Avalia o processo de } \\
\text { ensino-aprendizagem em } \\
\text { diferentes momentos de } \\
\text { interação com o aluno em } \\
\text { um processo construtivo }\end{array}$ & $\begin{array}{l}\text { "Como você vai basear uma coisa que a pessoa tem } 1 \text { dia pra } \\
\text { mostrar o que aprendeu em } 2 \text { meses inteiros, concentrar tudo } \\
\text { naquilo, vai que um dia a pessoa acorda passando mal, brigou com a } \\
\text { mãe, com o pai, enfim por N razoes ela não ta bem pra fazer a prova } \\
\text { e ela não consegue ter um bom desempenho e você vai julgar um } \\
\text { bimestre inteiro em um dia. " } \\
\text { "A avaliação tem que ser por completo, a prova que a gente faz não } \\
\text { dá pra avaliar como um todo. Deve-se avaliar por um tempo, avaliar } \\
\text { nos momentos o aluno, não num momento só, mas em todos os } \\
\text { momentos, sempre avaliando o aluno, para notar se aprendeu, se ta } \\
\text { participando da aula e demonstrando conhecimento, e se não } \\
\text { aprendeu deve mostrar que não." }\end{array}$ \\
\hline
\end{tabular}



sala de aula com entusiasmo, envolvendo os alunos no processo de aprendizagem
5 - Conduz as atividades em

"Ele tem que gostar do que faz também, porque as vezes o professor não gosta e vem pra escola de má vontade e prejudica todo mundo, ele tem que gostar daquilo e aceitar as duvidas e acolher os alunos. se a pessoa vem trabalhar sem estimulo algum, isso vai passar pros alunos e para as outras pessoas, não vai ser algo produtivo."

"Eu acho que parte do que influencia muito o aluno, pelo menos pra mim é a questão do entusiasmo, eu vejo o professor entusiasmado, eu fico também, quando o professor não ta, não da vontade de aprender."

"O professor tem que gostar da matéria, porque a gente também sente essa ligação, essa é a diferença. Mas acho que isso influencia na percepção do conteúdo."

"O jeito de falar, quando o professor não gosta, ele passa e pronto, não aprofunda. Ele ate acaba a aula rápido quando não gosta. $\mathrm{E}$ você fica ate meio devagar, não to entendendo nada então nem vou prestar atenção."

"Quando o professor ta entusiasmado, parece que o tempo passa mais rápido, você entende tudo e ele usa o período da aula inteiro." "Aquele professor entusiasmado, você vê que ele ta gostando de dar aula."

"Eu acho que o professor não tem dentro dele que ele precisa acolher, ele precisa virar pro aluno e mostrar que ele é importante, que ele é parte daquilo que as idéias e participação dele é essencial praquilo. Se você mostrar pro aluno que ta chegando que ele é importante praquilo que a participação dele conta, que as idéias são

6 - Considera as idéias dos alunos permitindo que 0 aluno sinta-se importante no processo educacional

7 - Elogia os alunos de modo a valorizar seu empenho e dedicação e estimulando-o a vencer as dificuldades

8 - Esclarece qualquer tipo de duvida apresentada pelos alunos boas, o aluno se interessa, e dessa maneira o professor acolhe, e cria laços de confiança."

"Você passa muito tempo da sua vida na escola, então na escola tem que ser o lugar onde você se sinta acolhido, como se fosse uma você vai estudar, assistir alguma coisa, desenvolver esse lado escola-casa-familia."

"O professor tem que ensinar com o aluno, na só para o aluno, tem que ta junto, caminhando bem, porque quando não tem essa harmonia, desanda e não da mais certo."

"Ele tem que acreditar nos alunos e saber que ele pode ate se presidente.

Acreditar no aluno é acreditar no potencial"

"Então o professor tem que falar que você tem capacidade, que você pode aprender, que pode ser mais difícil que historia, geografia, pra quem tem mais afinidade, mas que se você se esforçar você pode aprender."

"O professor não pode subestimar o aluno, não é porque ele tem dificuldade que ele não vai aprender nunca, principalmente no momento da dificuldade ele tem que estar do lado e apoiar para superar as dificuldades."

"Às vezes você pergunta e ele fala: como assim você não entendeu? Aí você não pergunta mais. "

"Uma vez aconteceu isso comigo e ai depois e guardei todas as perguntas pra mim..."

"Às vezes ele gosta tanto da matéria que fica fácil pra ele, então ele tem que ver o lado do aluno."

"Tem que ser aberto aos alunos ter essa confiança de tirar duvidas." "Então o professor deve ser capaz de deixar o aluno confortável na aula, pra tirar duvidas, e entender a matéria." extensão da sua casa, e que você vai se sentir bem independente se 
9 - Mantém a disciplina em sala de forma respeitosa, proporcionando um ambiente favorável ao estudo diversificadas para atender às dificuldades de aprendizagem de cada turma de alunos

11 - Utiliza linguagem de fácil compreensão pelos alunos
"Então acho que os alunos tem capacidade de ser cobrados, e realmente estar em sala, é ambiente de estudo, e o professor tem que cobrar isso."

"E acho também que ter mais rigidez. O professor tem que exercer autoridade, já notei que hoje em dias as turmas querem mandar no professor, isso ta errado e quanto mais isso acontece, menos a gente aprende."

"O professor não precisa se impor também."

"Eles têm que ter a capacidade, não de mudar de didática, mas mudar o jeito dele falar, porque as pessoas são diferentes, são turmas, e cada turma tem um perfil especifico, um jeito de entender, um tempo..."

"Outra coisa importante, é que muito professor fala: 'Ah, a gente tá atrasado em relação a tal turma" - cada turma é uma turma, ele tem que saber tratar as diferenças..."

"...entender o porquê do atraso daquela turma..."

"Ele não tem que comparar com outra turma..."

"É porque às vezes o jeito de pensar do professor não é o mesmo do nosso."

"Tem um professor que fez algo muito legal ele passou exercício e colocou os alunos que sabiam mais para ajudar a explicar. E ai a gente tirava duvida com os amigos, que tem a mesma linguagem, ficava mais fácil."

"Acho que mudou muito a forma como a gente estuda. Hoje a gente usa muito Power Point, coisas mais tecnológicas."

"Acho que isso é muito bom porque dá uma dinâmica diferente pras aulas."

"O professor deve saber usufruir mais disso porque fica mais interessante.

12 - Utiliza de forma dinâmica e criativa diferentes recursos tecnológicos e didáticos ao ensinar,

sem desviar o foco do conteúdo
Tem umas aulas que ficam na sua cabeça e você não esquece às vezes não pela matéria, mas como ela foi abordada."

"...Tem que mostrar de jeito dinâmico, sem ser só aquela aula expositiva, mais dinâmico, tipo Power Point."

"O professor tem que fugir do padrão também. A aula fica monótona se toda aula é igual. Os professores que são diferentes todo mundo gosta todo mundo presta atenção e fica entusiasmado em aprender." "... forma de explicar ajuda muito: usar musicas, etc."

"A aula pode ser engraçada, mas dentro da matéria..não fugir do assunto."

"Acho também que o professor ta na sala, pra passar a matéria que deve passar, tem muito professor que desvia do foco"

"...Porque ninguém pensa do mesmo jeito, então nem todo mundo entende a matéria..."

"...Então ele tem que ter a capacidade de mudar a forma com que ele fala..."

"...Cada pessoa tem um tempo, tem um jeito, então eu acho que dinamizar a forma como ele fala, ajuda os alunos a entenderem, porque às vezes ele mostrando de uma forma, algumas pessoas entendem outras não."

"O professor tem que ensinar de um jeito que todo mundo entenda.

Por mais que ele explique, nem todo mundo entende" 
14 - Utiliza exemplos relacionados à realidade dos alunos a fim de facilitar a aprendizagem
"O professor tem que mostrar o que realmente representa aquele conceito."

"Pra que eu vou usar distribuição eletrônica? Se o professor não me mostrar onde vou usar é difícil. O importante é trazer isso pro contexto."

"O professor tem que saber fazer isso: contextualizar. Duvido que alguém aqui pega uma página do jornal de economia e entende. Mas aquilo é importante."

"É importante contextualizar, tipo, 'ah o avião caio por causa disso, disso e disso', mesmo que eu não vá usar, eu acho interessante e quero aprender aquilo, eu quero sabe porque é assim..."

"Eu acho que ele teria que dominar a matéria e colocar num contexto, não só ler o slide e explicar aquilo, tem que ir alem, ter um contexto por fora."

Quadro 4: Competências na percepção dos alunos

No grupo focal dos alunos, as contribuições foram direcionadas a aspectos ligados a competências para a aprendizagem efetiva. Em algumas delas, o foco era no comportamento do professor frente aos recursos utilizados para realizar com sucesso o seu processo de ensino-aprendizagem, como as competências de números $2,3,4,5,8,9,11,12,13$ e 14. As demais competências podem ser relacionadas à interação entre professor e aluno, ou seja, a postura que o professor apresenta em relação aos alunos, de forma também a facilitar também o processo de ensinoaprendizagem.

\subsubsection{Competências de acordo com a percepção de gestores}

\begin{tabular}{|c|l|}
\hline Competência & Falas \\
\hline $\begin{array}{c}\text { 1 - Abre espaço para o } \\
\text { diálogo e estimula a } \\
\text { participação dos alunos }\end{array}$ & $\begin{array}{c}\text { "O professor deve ter liderança numa gestão democrática, uma coisa } \\
\text { é gerir um grupo com regras autoritárias, outra coisa é numa gestão } \\
\text { democrática." } \\
\text { "A gestão democrática é no sentido de entender que no espaço de } \\
\text { autoridade instituíla e tem alunos que tem características de } \\
\text { liderança e eles têm que ter espaço para se posicionar pra ter voz, } \\
\text { pra criticar de forma construtiva, para contribuir para a dinâmica do } \\
\text { grupo, para que naquele espaço não se faça só o que o professor } \\
\text { determina, que há espaço para dialogo, para tomada de decisões. " } \\
\text { "Tem que saber se comunicar, quem sabe se comunicar sabe ouvir. }\end{array}$ \\
$\begin{array}{c}\text { O ouvir é pouco praticado na relação professor aluno, mas muito } \\
\text { requisitado pelos alunos. " }\end{array}$ \\
$\begin{array}{c}\text { vividas e ressalta posturas } \\
\text { condizentes com os valores } \\
\text { da instituição durante os } \\
\text { momentos de interação com } \\
\text { os alunos, a fim de contribuir } \\
\text { para a formação integral do } \\
\text { adolescente. }\end{array}$ & $\begin{array}{l}\text { "Deve-se despertar nos jovens alem da questão da aprendizagem e } \\
\text { conhecimento, deve despertar o jovem para o lado espiritual, social, } \\
\text { cientifico, que se relacione bem, que seja ambiental, o professor deve } \\
\text { ter olhar de varias vertentes para alem do conhecimento dele." } \\
\text { "É preciso orientar o jovem, que tipo de conduta uma escola marista } \\
\text { espera dele" }\end{array}$ \\
\hline
\end{tabular}


3 - Apresenta o conteúdo da disciplina de forma clara e objetiva
"É essencial ser muito bom na área que se propôs, ser bom geólogo, muito bom significa saber como o conhecimento se produziu e acompanha isso."

"Uma das competências fundamentais para o momento atual é a capacidade de comunicar independente da atividade, do equipamento ou da proposta que se tenha, a qualidade de comunicação que se estabelece a partir da atividade é que garante a qualidade do ensino."

"O professor precisa ser um bom comunicador"

4 - Busca soluções diferenciadas para situações imprevistas

5 - Conduz as atividades em sala de aula com entusiasmo, envolvendo os alunos no processo de aprendizagem

6 - Dá atenção aos alunos buscando compreender as necessidades e contribuir para a solução de suas dificuldades

7 - Fornece orientações aos alunos para realizarem análise crítica nos seus momentos de estudo

8 - Identifica os objetivos e
planeja a didática da aula

9 - Mantém a motivação e supera as dificuldades encontradas

10 - Mantém postura equilibrada e educada em situações de conflito e contribui para a sua solução
"Ele tem que ser criativo para buscar alternativas que se adequem a situações que tomam rumos diferentes do planejado, as vezes ser muito organizado passa a ser um problema. Devo buscar alternativas e rever o planejado."

"O entusiasmo é muito importante. Mostra que conhece o que ta falando, isso prende a atenção do aluno, se concentra no que está sendo falado, o aluno tem interesse na sala de aula."

"A afetividade passa pela questão da empatia, do professor compreender o momento de vida do jovem, saber se colocar no lugar dele, ter um olhar cuidadoso, de respeito de atenção, não Necessariamente ser bonzinho, nada disso. Ser afetivo é ser firme, ser rigoroso, mostrar preocupação com a pessoa. Mesmo quando há punição, há demonstração de cuidado, afetivo no sentido de mostrar preocupação."

"O foco ainda é o ensino, a diferença é que se antes a diferença é do conteúdo, hoje o ensino é de habilidades, habilidade de estudar, de refletir, de fazer síntese, analise, argumentação, e ter uma pessoa que foco o ensino no desenvolvimento de habilidades e não apenas conteúdo"

"A aula não começa nem termina na sala de aula, todo esse processo exige que o professor pense cuidadosamente isso, não apenas planejar: o que é que eu desejo? Pretendo? O que esperam de mim? Qual a minha pauta? Quais os objetivos? Qual o conteúdo? Que resultados atingir? Isso mostra que o professor precisa aprender a fazer, assumir a complexidade do trabalho. O professor deve superar a improvisação, deve haver pensar."

"Saber lidar com a incompletude do processo de formação e saber lidar com as expectativas. Com quarenta eu acertei, mas um eu não atingi, o professor alimenta um sentimento de fracasso. E a incompletude é natural no processo de formação. Nuca ninguém vai estar pronto por si só ou por dependência de um professor, então o professor deve ser flexível com si mesmo e com o outro, resiliente." "Quando algo o desestabiliza e ele não sabe lidar, ele também não sabe lidar com a crise do aluno."

"Fica cada dia mais claro que não foram educados para lidar com crise.

E o processo educativo tem relação diária com a crise. "

"A educação passa pela crise, o professor que não sabe lidar com a crise, não sabe lidar com a crise do aluno."

"Nós não sabemos lidar com a crise."

'O conflito na escola precisa ser visto como algo saudável, a própria família, a sociedade bane o conflito, ela não percebe como um momento rico de troca e conhecimento." 


\begin{tabular}{|c|l|}
$\begin{array}{c}11 \text { - Planeja as aulas } \\
\text { distribuindo as atividades de } \\
\text { modo a facilitar o processo } \\
\text { de ensino-aprendizagem }\end{array}$ & "Aqui no Marista talvez a primeira competência seja amar, mas por \\
amar se entende: ensino de excelente qualidade e acolhida rigorosa \\
o que é amar? Amar é dar o que tem de melhor, e o que é o \\
professor dar o que tem de melhor? E se dedicar, o que passa por \\
este viés, é muito claro, o fato de amar é querer que o aluno seja o \\
melhor"
\end{tabular}

Quadro 5: Competências na percepção dos gestores

Além de apresentarem algumas competências relacionadas à sala de aula, ao momento do ensino, à relação professor aluno, e à formação do jovem, os gestores contribuíram com competências relacionadas também à questões extra sala de aula $\mathrm{e}$ posturas pessoais necessárias para o trabalho de qualidade, como por exemplo: "Realiza levantamentos sobre as características de seus alunos de forma a compreender suas particularidades"; "Revê atitudes adotadas em sala de aula a partir de criticas e auto-avaliação", "Mantém postura equilibrada e educada em situações de conflito e contribui para a sua solução", "Mantém a auto - motivação e supera as dificuldades encontradas". 


\subsubsection{Competências de acordo com a percepção de professores}

Por último são apresentadas as competências sob o ponto de vista dos professores, conforme Quadro 5.

\begin{tabular}{|c|c|}
\hline Competências & Falas \\
\hline $\begin{array}{l}1 \text { - Apresenta experiências } \\
\text { vividas e ressalta posturas } \\
\text { condizentes com os valores } \\
\text { da instituição durante os } \\
\text { momentos de interação com } \\
\text { os alunos, a fim de contribuir } \\
\text { para a formação integral do } \\
\text { adolescente. }\end{array}$ & $\begin{array}{l}\text { "Quando você entra no marista, já conhece a instituição sabe que } \\
\text { tem alguns princípios básicos, principalmente na questão da } \\
\text { formação como um todo, não é mais o papel do professor, e sim do } \\
\text { educador marista. A questão de valores é muito importante. Aqui fica } \\
\text { claro que se a função da escola fosse apenas transmitir } \\
\text { conhecimentos, a escola poderia fechar as portas. Aqui vai muito } \\
\text { além dessa parte de transmissão de conhecimento, ainda é muito } \\
\text { valorizada a formação do todo." } \\
\text { "Eu vejo que também esse papel de orientador é importante, eu me } \\
\text { sinto todos os dias orientando, essa parte moral, educativa, é o que } \\
\text { existe como referencia" } \\
\text { "Sobretudo a orientação da instituição que inclusive assume um } \\
\text { profissional na expectativa que ele vá na direção dos seus } \\
\text { propósitos, então ele tem que estar em sintonia. Porque nem sempre } \\
\text { aquela indicação vai ser de sua concordância e você tem que } \\
\text { trabalhar esse conflito" }\end{array}$ \\
\hline $\begin{array}{l}2 \text { - Apresenta o conteúdo da } \\
\text { disciplina de forma clara e } \\
\text { objetiva }\end{array}$ & $\begin{array}{l}\text { "Conhecimento da disciplina é condição sine qua non para ser } \\
\text { professor." } \\
\text { "Você tem que ter domínio de conteúdo" }\end{array}$ \\
\hline $\begin{array}{l}3 \text { - Conduz as atividades em } \\
\text { sala de aula com } \\
\text { entusiasmo, envolvendo os } \\
\text { alunos no processo de } \\
\text { aprendizagem }\end{array}$ & $\begin{array}{l}\text { "Hoje os alunos têm percebido muito isso: você gostar daquilo que } \\
\text { você faz. Pode ser que um dia ou outro você chegue mais chateado, } \\
\text { mas não adianta que você não engana o aluno, ele percebe } \\
\text { claramente se você faz algo que você gosta ou não. Em qualquer } \\
\text { profissão, se alguém faz o que não gosta, ta sofrendo e muito. " }\end{array}$ \\
\hline $\begin{array}{l}4 \text { - Demonstra para o aluno } \\
\text { o valor do conteúdo para sua } \\
\text { vida profissional }\end{array}$ & $\begin{array}{l}\text { "Nosso trabalho é feito para um cliente que na maioria das vezes não } \\
\text { quer o produto. Então política no sentido de você tentar fazer com } \\
\text { que ele perceba que aquilo é importante para ele. " }\end{array}$ \\
\hline $\begin{array}{l}5 \text { - Fornece orientações aos } \\
\text { alunos para realizarem } \\
\text { análise crítica nos seus } \\
\text { momentos de estudo }\end{array}$ & $\begin{array}{l}\text { "Dentro da minha área recebo perguntas de alunos de atualidades, } \\
\text { de exposições, fatos da internet, querendo esclarecimentos porque } \\
\text { não tem o habito maior de pesquisa, eles não sabem ir atrás do } \\
\text { conhecimento, o professor alem da questão do valor, tem um papel } \\
\text { instrucional e de ensiná-lo a organizar as informações, em } \\
\text { determinados momentos, é preciso lembrá-los onde sublinhar o texto, } \\
\text { onde copiar. Âs vezes perguntam tem que levar o caderno? Eles não } \\
\text { têm esse hábito." } \\
\text { "O papel passa pela questão instrucional e também de facilitar a } \\
\text { organização do estudo do aluno. Aqui é feito também o papel de } \\
\text { entender como estudar." } \\
\text { "Mas dessa parte acadêmica é mais o papel, ensinar o aluno a } \\
\text { estudar, a maior parte da informação ele vai perder se não usar, vai } \\
\text { esquecer" }\end{array}$ \\
\hline
\end{tabular}


6 - Mantém a disciplina em sala de forma respeitosa, proporcionando um ambiente favorável ao estudo
"Ambiente saudável, disciplina, há momentos que você pode descontrair, deve descontrair, tem que ter bom relacionamento com alunos, mas há momentos que a seriedade se faz necessária e você tem que conseguir essa seriedade mesmo que tenha que ser duro" "Acho que é proporcionar a todos um ambiente de estudo, um ambiente necessário ao estudo, se é uma discussão em grupo, que eles estejam dispostos de tal maneira e saibam que fazer gracinha atrapalha o outro grupo, manter um ambiente saudável para o estudo. Em outro momento, se é uma leitura de um texto, eu preciso de silencio. Existem aqueles que têm um nível de concentração muito bom, então ta tendo bagunça em torno dele , e não te problema, mas tem aquele que se dispersa facilmente e se você não mantém um nível para aquela atividade, você vai prejudicar alguns."

"Tem que ter equilíbrio emocional para situações de stress extremo." "Agora uma habilidade desenvolvida é conseguir trabalhar num nível de estresse alto e conseguir lidar com humanos em toda a sua diversidade, esse são os dois princípios do professor, é a profissão que menos se pode errar. "

"Então o nível de estresse do professor não é somente lidar com a atividade em si, mas lidar com uma serie de variantes que estão a todo tempo olhando pra você. E você tem que transitar no meio dessas diversidades sem se deixar abalar."

"É igual andar na corda bamba, eu sinto isso o tempo todo, que to andando na corda bamba."

"Não pode deixar as emoções tomar conta das suas ações."

8 - Realiza pesquisas de forma a manter-se atualizado em relação à sua área e aos avanços científicos e tecnológicos

9 - Relaciona-se de forma harmônica, cordial e respeitosa com os diferentes atores que integram o colégio

10 - Utiliza exemplos relacionados à realidade dos alunos a fim de facilitar a aprendizagem
"Ao professor é demandado que ele tenha um bom nível de informação e uma informação bem atualizada. "

"Eu comparo muito com política, não só sentido pejorativo, é uma teia de relações, eu, os alunos, os outros professores, a direção da escola, os coordenadores, a assistência, tem que ter habilidade para lidar com as cabeças diferentes o tempo todo.A corda puxa para um lado, puxa pro outro. São varias coisas."

"Porque não é fácil lidar com interesses diversos, você tem que ter habilidade para isso."

"Habilidade política no sentido de saber lidar com as relações."

"Construção de pontes. Você tem a informação, mas não sabe o que fazer com ela, você não sabe estabelecer um link dessa informação com outra ou ate mesmo o contexto dessa informação, e o professor quando faz isso, contribui muito, eu percebo."

Quadro 6: Competências na percepção dos professores

As competências identificadas no grupo focal de professores foram identificadas também, em algum momento, na fala dos demais sujeitos pesquisados, apenas a competências de número 4: "Demonstra para o aluno o valor do conteúdo para sua vida profissional", foi acrescentada sob a percepção dos professores. O número de competências identificadas nas falas dos professores também foi reduzido em comparação com as outras análises. 
Analisando as competências percebidas pelos professores, percebe-se que a maioria delas são relacionadas a aspectos da prática docente para a aprendizagem efetiva, como as competências de número 2, 3, 4, 5, 6 e 10. Outras competências estão ligadas à posturas que o professor deve adotar mesmo que fora de sala de aula, são as competências: "Mantém postura equilibrada e educada em situações de conflito contribuindo para a sua solução"; "Realiza pesquisas de forma a manter-se atualizado em relação à sua área e aos avanços científicos e tecnológicos"; "Relaciona-se de forma harmônica, cordial e respeitosa com os diferentes atores que integram o colégio".

\subsection{Síntese dos Resultados}

O Quadro 7 representa uma síntese do que foi apresentado, ou seja, uma lista de todas as competências descritas de acordo com os diferentes grupos e pela análise documental, sendo que as competências similares foram agrupadas de forma e melhor representar os resultados do estudo que aponta as competências fundamentais aos docentes do Colégio Marista de Brasília - Ensino Médio.

\begin{tabular}{|c|c|c|c|c|c|}
\hline & Competências & Documental & Alunos & Gestores & Professores \\
\hline 1 & $\begin{array}{l}\text { Apresenta experiências vividas e ressalta } \\
\text { posturas condizentes com os valores da } \\
\text { instituição durante os momentos de interação } \\
\text { com os alunos, a fim de contribuir para a } \\
\text { formação integral do adolescente }\end{array}$ & $x$ & $x$ & $x$ & $x$ \\
\hline 2 & $\begin{array}{l}\text { Relaciona-se de forma harmônica, cordial e } \\
\text { respeitosa com os diferentes atores que } \\
\text { integram o colégio }\end{array}$ & $x$ & $x$ & $x$ & $x$ \\
\hline 3 & $\begin{array}{l}\text { Apresenta o conteúdo da disciplina de forma } \\
\text { clara e objetiva }\end{array}$ & & $x$ & $x$ & $x$ \\
\hline 4 & $\begin{array}{l}\text { Conduz as atividades em sala de aula com } \\
\text { entusiasmo, envolvendo os alunos no } \\
\text { processo de aprendizagem }\end{array}$ & & $x$ & $x$ & $x$ \\
\hline 5 & $\begin{array}{l}\text { Abre espaço para o diálogo e estimula a } \\
\text { participação dos alunos }\end{array}$ & $x$ & $x$ & $x$ & \\
\hline 6 & $\begin{array}{l}\text { Fornece orientações aos alunos para } \\
\text { realizarem análise critica nos seus momentos } \\
\text { de estudo }\end{array}$ & $x$ & & $x$ & $X$ \\
\hline 7 & $\begin{array}{l}\text { Mantêm a disciplina em sala de forma } \\
\text { respeitosa, proporcionando um ambiente } \\
\text { favorável ao estudo }\end{array}$ & $x$ & $x$ & & $x$ \\
\hline 8 & $\begin{array}{l}\text { Utiliza estratégias didático-pedagógicas } \\
\text { diferenciadas de acordo com as } \\
\text { características dos alunos }\end{array}$ & & $x$ & $x$ & $x$ \\
\hline 9 & $\begin{array}{l}\text { Utiliza exemplos relacionados à realidade dos } \\
\text { alunos a fim de facilitar a aprendizagem }\end{array}$ & $x$ & $X$ & & \\
\hline
\end{tabular}




\begin{tabular}{|c|c|c|c|c|c|}
\hline 10 & $\begin{array}{l}\text { Elogia os alunos de modo a valorizar seu } \\
\text { empenho e dedicação e estimulando-o a } \\
\text { vencer dificuldades }\end{array}$ & $x$ & $x$ & & \\
\hline 11 & $\begin{array}{l}\text { Realiza atividades diversificadas para atender } \\
\text { às dificuldades de aprendizagem de cada } \\
\text { turma de alunos }\end{array}$ & $x$ & $x$ & & \\
\hline 12 & $\begin{array}{l}\text { Mantém postura equilibrada e educada em } \\
\text { situações de conflito e contribui para a sua } \\
\text { solução }\end{array}$ & & & $x$ & $x$ \\
\hline 13 & $\begin{array}{l}\text { Revê atitudes adotadas em sala de aula a } \\
\text { partir de criticas e auto-avaliação }\end{array}$ & $x$ & & $x$ & \\
\hline 14 & $\begin{array}{l}\text { Realiza pesquisas de forma a manter-se } \\
\text { atualizado em relação à sua área e aos } \\
\text { avanços científicos e tecnológicos }\end{array}$ & $x$ & & & $x$ \\
\hline 15 & $\begin{array}{c}\text { Cumpre prazos de entrega dos compromissos } \\
\text { assumidos }\end{array}$ & $x$ & & & \\
\hline 16 & $\begin{array}{l}\text { Orienta individualmente os alunos no seu } \\
\text { cotidiano escolar, nas atividades de estudo de } \\
\text { meio e nas atividades culturais }\end{array}$ & $x$ & & & \\
\hline 17 & $\begin{array}{l}\text { Participa ativamente de atividades } \\
\text { obrigatórias de formação continuada com } \\
\text { empenho e dedicação }\end{array}$ & $x$ & & & \\
\hline 18 & $\begin{array}{l}\text { Participa, de forma ativa, de atividades extra- } \\
\text { curriculares oferecidas pela escola }\end{array}$ & $x$ & & & \\
\hline 19 & $\begin{array}{l}\text { Avalia o processo de ensino-aprendizagem } \\
\text { em diferentes momentos de interação com o } \\
\text { aluno, em um processo construtivo }\end{array}$ & & $x$ & & \\
\hline 20 & $\begin{array}{l}\text { Considera as ideias dos alunos permitindo } \\
\text { que o aluno sinta-se importante no processo } \\
\text { educacional }\end{array}$ & & $x$ & & \\
\hline 21 & $\begin{array}{l}\text { Esclarece qualquer tipo de duvida } \\
\text { apresentada pelos alunos }\end{array}$ & & $x$ & & \\
\hline 22 & $\begin{array}{l}\text { Utiliza de forma dinâmica e criativa } \\
\text { diferentes recursos tecnológicos e didáticos } \\
\text { ao ensinar, sem desviar o foco do conteúdo }\end{array}$ & & $x$ & & \\
\hline 23 & $\begin{array}{c}\text { Utiliza linguagem de } \\
\text { fácil compreensão pelos alunos }\end{array}$ & & $x$ & & \\
\hline 24 & $\begin{array}{l}\text { Busca soluções diferenciadas para situações } \\
\text { imprevistas }\end{array}$ & & & $x$ & \\
\hline 25 & $\begin{array}{l}\text { Dá atenção aos alunos buscando } \\
\text { compreender as necessidades e contribui } \\
\text { para a solução de suas dificuldades }\end{array}$ & & & $x$ & \\
\hline 26 & $\begin{array}{l}\text { Mantém a auto-motivação e supera as } \\
\text { dificuldades encontradas }\end{array}$ & & & $x$ & \\
\hline 27 & $\begin{array}{l}\text { Planeja as aulas distribuindo as atividades de } \\
\text { modo a facilitar o processo de ensino- } \\
\text { aprendizagem }\end{array}$ & & & $x$ & \\
\hline 28 & $\begin{array}{l}\text { Realiza levantamentos sobre as } \\
\text { características de seus alunos de forma a } \\
\text { compreender suas particularidades }\end{array}$ & & & $x$ & \\
\hline 29 & $\begin{array}{l}\text { Demonstra para o aluno o valor do conteúdo } \\
\text { para sua vida profissional }\end{array}$ & & & & $x$ \\
\hline
\end{tabular}

Quadro 7: Síntese das competências 
Com o quadro-síntese apresentado é possível observar algumas características. No total, foram definidas 29 competências fundamentais.

Ao realizar a análise documental, percebe-se que muitos objetivos estão ligados à questão de formação de valores dos alunos, pelo fato de ser uma instituição católica, os valores humanos e a evangelização do jovem são extremamente citadas nos objetivos institucionais. Observa-se nos documentos que muitas dessas práticas evangelizadoras não competem somente aos professores e sim às unidades organizacionais responsáveis na Escola. Porém, a disseminação destes valores e a formação do jovem são também de responsabilidade do educador Marista, uma vez que ele é o representante da Escola que tem maior contato com o aluno. A importância deste fato pode ser constatada ao notarem-se as únicas competências que foram citadas pelas quatro fontes de pesquisa: a competência de número 1 e a de número 2, respectivamente: "Apresenta experiências vividas e ressalta posturas condizentes com os valores da instituição durante os momentos de interação com os alunos, a fim de contribuir para a formação integral do adolescente" e "Relaciona-se de forma harmônica, cordial e respeitosa com os diferentes atores que integram o colégio". Podem-se considerar, portanto, estas competências como sendo umas das mais importantes para o professor do Colégio Marista, no ponto de vista da Instituição.

As competências que aparecem com uma freqüência de três citações (competências de número $3,4,5,6,7$ e 8), são bem distribuídas quanto às fontes. Os gestores, professores e alunos tiveram participação em cinco delas e os documentos em três competências. A distribuição destas competências entre os sujeitos pesquisados ficou bem dispersa.

Nas competências que tiveram uma citação de freqüência dois $(9,10,11,12$, 13 e 14), também foram bem distribuídos quanto à fonte citada, não havendo nenhuma dupla de fonte que tenha se destacado.

As demais competências que tiveram freqüência um, ou seja, foram citadas por apenas uma das fontes (documentos, alunos, gestores ou professores), são maioria, totalizando 15 competências. Isso pode ser pelo fato dos diversos "atores" do processo possuírem diferentes pontos de vista em relação à forma como este professor deve apresentar um desempenho de qualidade. Um fato interessante é que destas competências apenas uma delas foi citada pelos professores, "Demonstra para o aluno o valor do conteúdo para sua vida profissional", o que representa que as 
demais competências percebidas por eles como fundamentais também são percebidas por outras fontes de pesquisa. As demais competências ficaram proximamente divididas em relação aos documentos, gestores e alunos, sendo estes dois últimos os que mais contribuíram com a percepção de competências docentes, totalizando um total de cinco competências.

Observa-se que apenas oito competências foram citadas por três ou mais fontes de pesquisa. Isso não desqualifica a importância das demais competências, uma vez que, todas as fontes de coleta de dados são de fundamental importância para o processo educacional. Dessa maneira, é relevante considerar tais competências principalmente pelo fato de que muitas delas foram citadas pelos alunos, que podem ser considerados neste cenário os principais sujeitos do processo.

Algumas competências apresentadas possuem certa familiaridade com competências identificadas nos estudos de Campos (2008) e Perrenoud (2000).

A competência de número 22 assemelha-se à competência apresentada por Perrenoud (2000): "Utilizar novas tecnologias". Já a competência "Organizar e dirigir situações de aprendizagens", também apresentada por Perrenoud (2000) aborda questões como conhecer a disciplina e conteúdos abordados, trabalhar a partir dos erros e dos obstáculos à aprendizagem, envolver os alunos em atividades de pesquisa, em projetos de conhecimento e ainda construir e planejar dispositivos e seqüências didáticas. Tais pontos também podem ser identificados nas competências apresentadas pela pesquisa: $3,6,8,9,10,11,24$ e 27 .

Uma competência também abordada por Perrenoud (2000) é a de "Administrar a progressão da aprendizagem", que aborda a questão de observar e avaliar alunos em situações de aprendizagem de acordo com uma abordagem formativa, competência esta próxima à apresentada pela competência 19: "Avalia o processo de ensino-aprendizagem em diferentes momentos de interação com o aluno, em um processo construtivo".

Outra competência específica abordada por Perrenoud (2000) está relacionada a administrar a heterogeneidade no âmbito da turma, competência esta próxima à competência 28 . As competências de numero 13 e 14 também estão muito próximas à competência abordada por Perrenoud: "Administrar sua própria formação contínua".

Em relação à pesquisa de Campos (2008), existem algumas similaridades, mas devido ao fato da pesquisa ser direcionada professores gestores, algumas 
competências não se aplicam à realidade desta pesquisa. Considerando as particularidades da pesquisa do autor, algumas competências podem ser consideradas similares, pois quatro se assemelham a esta pesquisa: Resolver os problemas por meio da criatividade; Compartilhar dos interesses institucionais; Induzir o envolvimento dos outros; Ter capacidade política; sendo associadas respectivamente às competências: 24, 9, 5 e 2 .

Além dos estudos apresentados, outros autores e fontes citam competências docentes, e podem-se compará-los aos resultados apresentados. A abordagem apresenta pelos diversos sujeitos da pesquisa que considera o professor como educador e responsável também pela formação do aluno, apresentada na competência: "Apresenta experiências vividas e ressalta posturas condizentes com os valores da instituição durante os momentos de interação com os alunos, a fim de contribuir para a formação integral do adolescente", pode ser comparada à uma parte do artigo 35 da Lei de Diretrizes e Bases № 9.394, de 20 de dezembro de 1996 (BRASIL, 1996) que sustenta que o Ensino Médio tem como finalidade: "O aprimoramento do educando como pessoa humana, incluindo formação ética e o desenvolvimento da autonomia intelectual e do pensamento crítico"; esta ultima parte também está vinculada à competência "Fornece orientações aos alunos para realizarem análise crítica nos seus momentos de estudo".

A competência de número 14: "Realiza pesquisas de forma a manter-se atualizado em relação à sua área e aos avanços científicos e tecnológicos" pode ser validada pela abordagem de Martins (2001, p.78) que considera " a ausência de formação inicial adequada dos professores como um dos fatores mais dificultadores de mudança nas posturas sacralizadas de ensino". Dessa maneira, observa-se a importância da constante atualização do professor para gerar mudanças no ensino.

A competência "Utiliza exemplos relacionados à realidade dos alunos a fim de facilitar a aprendizagem" pode também ser fundamentada pela necessidade de se manter a interdisciplinariedade, a transversalidade e a contextualização, e a integração de áreas em projetos de ensino como citado por Mello (2000).

Por ultimo, e citando mais uma vez duas competências já apresentadas: "Fornece orientações aos alunos para realizarem análise crítica nos seus momentos de estudo" e "Utiliza exemplos relacionados à realidade dos alunos a fim de facilitar a aprendizagem" têm uma ligação muito forte com discussão de autores que concordam que o professor já não é mais a única fonte de conhecimento para o aluno (MELLO, 
2000), dessa maneira, "fortalece-se o papel que o professor sempre teve de ajudar o aluno a dar sentido às informações, avaliando, criticando, compreendendo, julgando a pertinência e aplicando-as na vida prática." (MELLO, 1999, p.4)

Observa-se então que muitas das competências identificadas na pesquisa são também citadas por outros autores como de importância para um desempenho docente de qualidade.

A seguir, serão apresentadas as considerações finais do estudo. 


\section{CONSIDERAÇÕES FINAIS}

O presente estudo teve como principal objetivo identificar as competências fundamentais para professores de uma instituição educacional de ensino médio.

A utilização de análise documental e realização de grupos focais com diferentes níveis hierárquicos da escola permitiram à pesquisadora descrever uma grande quantidade de competências.

Com a metodologia utilizada foi possível identificar quais são estas competências. Porém é importante enfatizar que as competências identificadas neste estudo foram descritas a partir da percepção de uma amostra pequena da população existente, principalmente no caso de alunos e professores, o que representa outras competências possam ser identificadas caso o número de docentes e alunos fosse maior. O mesmo ocorre devido às particularidades da instituição estudada, provavelmente algumas competências apresentadas não seriam identificadas caso outra organização fosse objeto de pesquisa. Cabe ressaltar que se trata de uma Instituição privada, em uma Instituição Pública.provavelmente alguns resultados seriam modificados.

Ainda que menos da metade das competências tenha sido citada pela maioria das fontes pesquisadas (documentos, alunos, professores e gestores), nota-se que houve uma grande interface de identificação destas competências, ou seja, algumas delas foram identificadas por professores e gestores, outras por documentos e gestores, outras por gestores e alunos, o que significa que, de alguma maneira, são necessárias ao desempenho de qualidade do professor.

Observou-se que a maior contribuição às competências veio da análise documental e dos gestores e alunos que trouxeram diferentes aspectos relacionados ao desempenho de qualidade de um docente que atua no ensino médio em instituição privada de ensino. Todas as partes pesquisadas citaram questões relacionadas às posturas do professor em relação ao ensino da matéria e à formação do aluno. A pesquisa documental trouxe contribuições no campo de responsabilidades dos professores, os gestores contribuíram também com questões relacionada a competências do professor extra-sala de aula, a fim de aperfeiçoar sua prática docente. Os alunos argumentaram principalmente em relação aos comportamentos apresentados para que pudessem ter uma aprendizagem efetiva e sentirem-se participantes do processo de ensino-aprendizagem, em um clima amistoso. 
Observou-se ainda que as competências identificadas assemelham-se a competências identificadas em outros estudos, assim como em aspectos apontados por teóricos da área de Educação como essenciais a um ensino de qualidade.

Acredita-se que este estudo pode ser de suma importância para a organização pesquisada, uma vez que pode servir de insumo para uma avaliação destes professores e conseqüentes ações de melhoria para um desenvolvimento de desempenho de qualidade e alcance de objetivos institucionais.

Não somente a organização pesquisada pode utilizar-se das competências como também outras instituições de ensino médio podem, a partir do presente estudo, realizar mapeamento das competências dos docentes e desta forma estabelecer-se um comparativo tanto do desempenho como da importância destas competências para as diferentes escolas.

O estudo pode ser aplicado ainda a instituições públicas, a fim de identificar suas particularidades. Além disso, pode ser realizada uma avaliação no sentido de identificar a lacuna de competências destas instituições.

Conclui-se, portanto que o presente trabalho foi um estudo bem delineado em relação à sua metodologia e que os objetivos foram alcançados uma vez que se puderam identificar claramente as competências fundamentais para os professores da instituição pesquisada. 


\section{REFERÊNCIAS}

BRANDÃO, H.P.; GUIMARÃES, T.A. Gestão De Competências E Gestão De Desempenho: tecnologias distintas ou instrumentos de um mesmo construto?. Revista de Administração de Empresas, São Paulo, v. 41, n.1, p. 8-15, jan./mar. 2001.

H.P; BORGES-ANDRADE, J.E. Causas e feitos da expressão de competências no trabalho: para entender melhor a noção de competência. Revista de Administração Mackenzie, v. 8, n. 3, p. 32-49, out. 2007.

,H.P.; BAHRY, C.P. Gestão por competências: métodos e técnicas para mapeamento de competências. Revista do Serviço Público, Brasília, v. 56, n.2, p. 179-194, abr./jun. 2005.

BRASIL. Lei de Diretrizes e Bases da Educação Nacional nํ․ 9.394 de 20 de dezembro de 1996.

BRASLAVSKI, C. As novas tendências mundiais e as mudanças curriculares na educação secundária latino-americana na década de 90. Brasília: UNESCO, 2001.

BRUNO-FARIA, M.F.; BRANDÃO, H.P. Competências relevantes a profissionais de área de T\&D de uma organização pública do Distrito Federal. RAC, v. 7, n.3, p. 35-56, jul./set. 2003.

CAMPOS, D.C.S; SOUSA, N. B. ; CAMPOS, A. B. . Competências Gerenciais Necessárias aos professores-Gerentes que atuam em Pró-Reitorias: o caso de uma Instituição Federal de Ensino Superior de Minas Gerais. In: XXXII Encontro da ENANPAD, 2008, Rio de Janeiro. Anais. 2008.

CARBONE, P. P. et al. Gestão por Competências e Gestão do Conhecimento. Rio de Janeiro: FGV, 2005.

CRESWELL, J.W. Uma estrutura para projeto. In: Projeto de pesquisa: métodos qualitativo, quantitativo e misto. 2.ed. Porto Alegre: Artmed, 2007, cap.1.

DIAS, R.E; LOPES, A.C. Competências na formação de professores no Brasil: o que (não) há de novo. Educação e Sociedade, Campinas, v.24, n.85, dez. 2003.

DUTRA, J.S; HIPÓLITO, J.A.M; SILVA, C.M. Gestão de Pessoas por competências: o Caso de uma Empresa do Setor de Telecomunicações. RAC, v.4, n. 1, p. 161-176, jan./abr. 2000. 
- Competências: conceitos e instrumentos para a gestão de pessoas na empresa moderna. São Paulo: Atlas, 2007.

FLEURY, A.; FLEURY M.T. Construindo o Conceito de Competência. RAC, Edição Especial 2001: p. 183-196, 2001.

; Estratégias empresariais e formação de competências: um quebracabeça caleidoscópico da indústria brasileira. 3. ed. São Paulo: Atlas, 2007.

FREITAS, I.A; BRANDÃO, H.P. Trilhas de aprendizagem como estratégia para o desenvolvimento de competências. Anais do 29 Encontro da Associação Nacional dos Programas de Pós-Graduação em Administração. Brasília, ANPAD, 2005.

GATTI, B.A. Grupo focal na pesquisa em ciências sociais e humanas. Brasília: Liber Livro, 2005.

GUIMARÃES, T.A; BRUNO-FARIA, M.F; BRANDÃO, H.P. Aspectos metodológicos do diagnóstico de competências em organizações. In: BORGES-ANDRADE, J.E; ABBAD, G.S; MOURÃO, L. Treinamento, desenvolvimento e educação em organizações do trabalho: fundamentos para a gestão de pessoas. Porto Alegre: Artmed, 2006. cap.11

HAMEL, G.; PRAHALAD, C.K. Competindo pelo futuro: estratégias inovadoras para obter o controle do seu setor e criar os mercados de amanhã. Rio de Janeiro: Campus, 1997.

HANASHIRO, D.M.M; NASSIF, V.M.G. Competências de professores: um fator competitivo. RBGN. v.8, n.20, p. 45-56, jan./abr., 2006.

LE BOTERF, G. Desenvolvendo as competências dos profissionais. Porto Alegre: Artmed, 2003.

MARTINS, A. M. Diretrizes curriculares nacionais para o ensino médio: avaliação de documento. Cadernos de Pesquisa, no 109, p. 67-87, março, 2000.

MELLO, G.N. Diretrizes curriculares para o ensino médio: por uma escola vinculada à vida. Revista Ibero Americana. n.20, p. 1-8, maio/ago, 1999.

Formação de professores para a educação básica: uma (re) visão radical. São Paulo em perspectiva. v. 14, n. 1, p. 98-110, 2000. 
NUNES, C.M.F. Saberes docentes e formação de professores: um breve panorama da pesquisa brasileira. Educação e Sociedade, Campinas, v.22, n. 74, p. 1-10, abr. 2001.

PERRENOUD, P. Dez novas competências para ensinar. Porto Alegre: Artmed, 2000.

SANTOS, A. C. O uso do método Delphi na criação de um modelo de competências. Revista de Administração, São Paulo, v.36, n. 2, p. 25-32, abr./jun. 2001.

VERGARA, S.C. Começando a definir a metodologia. In: Projetos e Relatórios de Pesquisa em Administração. 6.ed. São Paulo: Atlas, 2005. cap. 4.

ZARIFIAN, P. Objetivo Competência: por uma nova lógica. São Paulo: Atlas, 2001. 


\section{APÊNDICES}

\section{Apêndice A: Roteiro Grupo Focal}

- Orientações iniciais

- Auto-apresentação

- Apresentação dos objetivos da pesquisa e do grupo focal

- Explicar a forma de registro e solicitar autorização para gravação em áudio

- Falar sobre a questão do sigilo das informações

- Falar que a discussão se concentra em duas questões e, se necessário, demais perguntas serão feitas pela mediadora

- Falar da importância da participação de todos

- Comentar que o foco da discussão é na figura do professor e no que deve ser apresentado por este, não é momento de discutir pontos fracos da escola ou dos professores

- Não devem ser citados nomes

- Para gerar discussão: Quais são as principais atribuições de um professor dentro deste colégio (não necessariamente o que eles fazem hoje) para que este alcance seus objetivos?

- Pergunta Central: 0 que um professor deve ser capaz de fazer para apresentar um desempenho de qualidade?

- Outras perguntas podem ser feitas ao longo do grupo para explorar melhor as respostas.

- Ao final:

- Coletar as seguintes características dos participantes;

- Posição (aluno, professor, gestor)

- Idade

- Sexo

- Titulação (no caso de gestores e professores)

- Tempo de escola

- Deixar espaço aberto para quem quiser acrescentar mais alguma observação por escrito

- Colocar-se disponível para aqueles que quiserem conversar em particular

- Agradecer pela colaboração e disponibilidade 


\section{Apêndice B: Carta-convite Professores}

Brasília, 04 de maio de 2009.

\section{Caros Professores,}

Sou Clarissa Schmidt da Rocha, ex-aluna Marista, e atualmente, estudante do último semestre do curso de graduação em Administração da Universidade de Brasília.

Com a autorização do Colégio Marista de Brasília - Ensino Médio, estou realizando uma pesquisa para o trabalho de conclusão de curso (Monografia) sobre o tema: "Competências Fundamentais para Professores de Ensino Médio".

Esta pesquisa visa identificar as competências essenciais aos referidos docentes relacionadas a um desempenho de qualidade em suas funções e conseqüentemente da Instituição.

Para o sucesso deste trabalho, é essencial contar com a colaboração dos atores deste processo, no caso todos os docentes da Instituição.

Gostaria, portanto, de convidá-los para um grupo de discussão, visando identificar tais competências. O grupo terá duração de cerca de uma hora, e teremos, no máximo, dois encontros, em horário da melhor conveniência de todos. Cada grupo será composto por seis a oito participantes e serão formados quantos grupos forem necessários para que possamos contar com a participação do maior número de docentes possível.

Solicito a gentileza de confirmar a participação com a Alessandra Castro, da Central de Relacionamentos.

Aguardo retorno até o dia 14/05/2009

Agradeço desde já a colaboração de todos!

Atenciosamente, 


\section{Apêndice C: Carta-convite Gestores}

Brasília, 04 de maio de 2009.

Caros Assessores e Diretores,

Sou Clarissa Schmidt da Rocha, ex-aluna Marista, e atualmente, estudante do último semestre do curso de graduação em Administração da Universidade de Brasília.

Com a autorização do Colégio Marista de Brasília - Ensino Médio, estou realizando uma pesquisa para o trabalho de conclusão de curso (Monografia) sobre o tema: "Competências Fundamentais para Professores de Ensino Médio".

Esta pesquisa visa identificar as competências essenciais aos referidos docentes relacionadas a um desempenho de qualidade em suas funções e conseqüentemente da Instituição.

Para o sucesso deste trabalho, é essencial contar com a colaboração dos senhores, que são os gestores desta organização.

Gostaria, portanto, de convidá-los para um grupo de discussão, visando identificar tais competências. O grupo terá duração de cerca de uma hora, e teremos, no máximo, dois encontros, em horário da melhor conveniência de todos. Cada grupo será composto por seis a oito participantes e serão formados quantos grupos forem necessários para que possamos contar com o maior número de participantes.

Solicito a gentileza de confirmar a participação com a Alessandra Castro, da Central de Relacionamentos.

Aguardo retorno até o dia 14/05/2009

Agradeço desde já a colaboração de todos!

Atenciosamente, 


\section{Apêndice D: Carta-convite Alunos}

Brasília, 04 de maio de 2009.

Caro Aluno,

Sou Clarissa Schmidt da Rocha, ex-aluna Marista, e atualmente, estudante do último semestre do curso de graduação em Administração da Universidade de Brasília.

Com a autorização do Colégio Marista de Brasília - Ensino Médio, estou realizando uma pesquisa para o trabalho de conclusão de curso (Monografia) sobre o tema: "Competências Fundamentais para Professores de Ensino Médio".

Esta pesquisa visa identificar as competências essenciais aos referidos docentes relacionadas a um desempenho de qualidade em suas funções e conseqüentemente da Instituição.

Para o sucesso deste trabalho, é essencial contar com a sua colaboração, que é peça fundamental dentro deste processo educacional.

Gostaria, portanto, de convidá-lo para um grupo de discussão, visando identificar tais competências. O grupo terá duração de cerca de uma hora, e teremos, no máximo, dois encontros, em horário da melhor conveniência de todos.

Solicito a gentileza de confirmar a participação com o Marcelo Xibiu, da Pastoral.

Aguardo retorno até o dia 14/05/2009

Desde já, agradeço a sua colaboração!

Atenciosamente, 